\title{
Collisionally-Induced Dissociation of Substituted Pyrimidine Antiviral Agents: Mechanisms of Ion Formation Using Gas Phase Hydrogen/Deuterium Exchange and Electrospray Ionization Tandem Mass Spectrometry
}

\author{
Amin M. Kamel ${ }^{\mathrm{a}}$ and Burnaby Munson ${ }^{\mathrm{b}}$ \\ ${ }^{a}$ Department of Exploratory Medical Sciences, Pfizer Global Research and Development, Groton \\ Laboratories, Groton, Connecticut, USA \\ ${ }^{\mathrm{b}}$ Department of Chemistry and Biochemistry, University of Delaware, Newark, Delaware, USA
}

ESI and CID mass spectra were obtained for four pyrimidine nucleoside antiviral agents and the corresponding compounds in which the labile hydrogens were replaced by deuterium using gas-phase exchange. The number of labile hydrogens, $x$, was determined from a comparison of ESI spectra obtained with $\mathrm{N}_{2}$ and with $\mathrm{ND}_{3}$ as the nebulizer gas. CID mass spectra were obtained for $[\mathrm{M}+\mathrm{H}]^{+}$and $[\mathrm{M}-\mathrm{H}]^{-}$ions and the exchanged analogs, $\left[\mathrm{M}\left(\mathrm{D}_{\mathrm{x}}\right)+\mathrm{D}\right]^{+}$and $\left[\mathrm{M}\left(\mathrm{D}_{\mathrm{x}}\right)\right.$ $-\mathrm{D}^{-}$, produced by ESI using a SCIEX API-III ${ }^{\text {plus }}$ mass spectrometer. Protonated pyrimidine antiviral agents dissociate through rearrangement decompositions of base-protonated [M + $\mathrm{H}]^{+}$ions by cleavage of the glycosidic bonds to give the protonated bases with a sugar moiety as the neutral fragment. Cleavage of the glycosidic bonds with charge retention on the sugar moiety eliminates the base moiety as a neutral molecule and produces characteristic sugar ions. CID of protonated pyrimidine bases, $[\mathrm{B}+\mathrm{H}]^{+}$, occurs through three major pathways: (1) elimination of $\mathrm{NH}_{3}\left(\mathrm{ND}_{3}\right)$, (2) loss of $\mathrm{H}_{2} \mathrm{O}\left(\mathrm{D}_{2} \mathrm{O}\right)$, and (3) elimination of HNCO (DNCO). Protonated trifluoromethyl uracil, however, dissociates primarily through elimination of $\mathrm{HF}$ followed by the loss of HNCO. CID mass spectra of $[\mathrm{M}-\mathrm{H}]^{-}$ions of all four antiviral agents show $\mathrm{NCO}^{-}$as the principal decomposition product. A small amount of deprotonated base is also observed, but no sugar ions. Elimination of $\mathrm{HNCO}, \mathrm{HN}_{3}, \mathrm{HF}, \mathrm{CO}$, and formation of iodide ion are minor dissociation pathways from $[\mathrm{M}-\mathrm{H}]^{-}$ions. (J Am Soc Mass Spectrom 2007, 18, 1477-1492) (C) 2007 American Society for Mass Spectrometry

S tructural characterization of antiviral nucleosides is particularly important in the synthesis of nucleoside analogs for studies of their tumor inhibitory properties and for the structural determination of modified nucleosides in RNA and DNA. The majority of antiviral agents are purine and pyrimidine nucleosides and nucleotides. Mass spectrometry has played a significant role in the characterization and analysis of pyrimidine antiviral agents [1-6]. Mass spectra of compounds containing the pyrimidine ring were first obtained by Biemann and McCloskey [7].

The nucleic acid bases constitute an important target for studies of the dissociation of heterocyclic compounds, primarily because of the importance of nucleic acid constituents as therapeutic drugs and their role in biotechnology and the human genome studies. The

Address reprint requests to Dr. A. M. Kamel, Department of Exploratory Medicinal Sciences, Pfizer Global Research and Development, Groton Laboratories, Groton, CT 06340, USA. E-mail: amin.m.kamel@pfizer.com ionic dissociation reactions of heterocyclic compounds have been regarded as some of the most complex processes in mass spectrometry. This view is due to practical limitations in the introduction of stable isotopes used to establish assignments of fragment ions and the complexity of the mass spectra obtained. Collision induced dissociation (CID) is advantageous for these studies and has been employed in the structural characterization of nucleobases. The collision process is an effective means of introducing sufficient internal energy into the protonated or deprotonated molecular ions to promote extensive fragmentation, which is minimal in ESI or API spectra. In addition, CID mass spectra of the compounds of interest can be obtained free of interferences that may be present in biological fluids or reaction mixtures. Collision induced dissociation has been employed in the structural characterization of pyrimidine nucleosides [8-16] and pyrimidine bases [17-20]. 
Negative ion mass spectrometry is useful because the spectra are often much simpler than positive ion mass spectra. Electrospray ionization (ESI) in the negative ion mode has been used for a variety of small molecules with acidic functionalities, such as carboxylic, phosphoric, and sulfonic acids groups [21-25]. Negative ion mass spectra of pyrimidine bases and pyrimidine nucleosides have also been reported [26-30].

The chemical incorporation of deuterium followed by mass spectrometry has played a major role in the structural characterization of molecules to provide information on the mechanisms of chemical or biological reactions, and in the interpretation of mass spectra [31-37]. We have recently used hydrogen/deuterium exchange to study the decomposition pathways for protonated and deprotonated tetracyclines [38] and purine antiviral agents [39]. This method requires only simple changes in the plumbing of a SCIEX API-III ion spray source, as described by Hemling and coworkers [40]. Effective exchange of active hydrogens was achieved by replacing the nebulizer gas $\left(\mathrm{N}_{2}\right)$ with $\mathrm{ND}_{3}$. The ESI gas-phase H/D exchange compares favorably with $H / D$ exchange methods in desorption chemical ionization and fast atom bombardment.

The present study was undertaken to determine the structures and mechanisms of formation of principal fragment ions of four pyrimidine antiviral agents and to determine the specific influence of substitution in the pyrimidine ring on the site selectivity of fragmentation pathways. Gas-phase hydrogen/deuterium exchange and tandem mass spectrometry in positive and negative ion modes were utilized to determine fragmentation processes. Knowledge of fragmentation mechanisms for CID spectra of $[\mathrm{M}+\mathrm{H}]^{+}$and $[\mathrm{M}-\mathrm{H}]^{-}$ions for these pyrimidine derivatives can serve as a useful models for structural determination of chemically or biologically modified antiviral agents as well as for quantitative determination in complex matrices.

\section{Experimental}

\section{Chemicals and Materials}

Four antiviral agents ( $3^{\prime}$-azido- $3^{\prime}$-deoxythymidine (AZT), trifluridine, 5-iodo- $2^{\prime}$-deoxyuridine and 5-iodo- $2^{\prime}, 3^{\prime}$ dideoxyuridine) were purchased from Sigma Chemical Co. (St. Louis, MO). Methanol and deionized water (HPLC-grade) were obtained from J. T. Baker (Phillipsburg, NJ). Glacial acetic acid and ammonium hydroxide (HPLC grade) were obtained from Fisher (Fair Lawn, NJ). Deuterated ammonia $\left(99+\% \mathrm{ND}_{3}\right)$ was obtained from Cambridge Isotopes Laboratories (Andover, MA).

\section{Hydrogen/Deuterium Exchange}

Gas-phase H/D exchange was used to determine fragmentation pathways of $[\mathrm{M}+\mathrm{H}]^{+}$and $[\mathrm{M}-\mathrm{H}]^{-}$ions of the antiviral agents. A modification was made to the SCIEX API-III ${ }^{\text {lus }}$ electrospray source to allow gas- phase H/D exchange in the nebulization region, as described by Hemling and coworkers [40]. Normal spectra and H/D exchanged spectra for a single injection were obtained by averaging 5 to 10 spectra with $\mathrm{N}_{2}$ as the nebulizer gas and then switching to $\mathrm{ND}_{3}$ for several scans and then switching to $\mathrm{N}_{2}$ for subsequent experiments. Both partially exchanged and fully exchanged species were observed. However, for these compounds it was easy to determine the number of exchangeable hydrogens from the mass shift of the most abundant mass species in the cluster.

\section{Sample Preparation and Introduction}

Each pyrimidine derivative was dissolved in $\mathrm{H}_{2} \mathrm{O}$ / $\mathrm{CH}_{3} \mathrm{OH}$ (1/1 by volume) to make a $10 \mu \mathrm{g} \mathrm{mL} \mathrm{m}^{-1}$ solution with $1 \% \mathrm{CH}_{3} \mathrm{COOH}$ or $50 \mathrm{mM} \mathrm{NH}_{4} \mathrm{OH}$ for positive or negative ion spectra, respectively. Recent work from this laboratory showed that $1 \% \mathrm{CH}_{3} \mathrm{COOH}$ or $50 \mathrm{mM}$ $\mathrm{NH}_{4} \mathrm{OH}$ significantly increased the sensitivities of pyrimidine derivatives in the positive or negative ionization mode, respectively [41]. Samples were infused into the electrospray interface using a Harvard syringe pump (South Natick, MA) at a flow rate of $2 \mu \mathrm{L} \mathrm{min}{ }^{-1}$.

\section{Mass Spectrometry}

Mass spectral analyses were performed with a SCIEX API-III ${ }^{\text {plus }}$ triple quadrupole mass spectrometer with a mass range to $2400 \mathrm{Da}$ (Thornhill, Ontario, Canada). The mass spectrometer was equipped with an ion spray interface with a nebulizer gas pressure $\left(\mathrm{N}_{2}\right)$ of 40 psi. The nitrogen curtain gas was adjusted to a flow rate of 1.2 $\mathrm{L} \mathrm{min}^{-1}$. Positive or negative ions formed at atmospheric pressure were sampled into the quadrupole mass filter via a 0.0045 in. diameter aperture. CID studies were performed in the second quadrupole on mass-sorted ions with Ar at a thickness of $\sim 2 \times 10^{15}$ atoms $/ \mathrm{cm}^{2}$ with collision energies of 5 to $25 \mathrm{eV}\left(\mathrm{MS}^{2}\right)$. Unit mass resolution was established, a 2 ms dwell time was selected, and the signal was averaged over 10 scans.

The SCIEX API-III ${ }^{\text {plus }}$ triple quadrupole mass spectrometer contains a feature that can increase fragmentation information in CID spectra. The potential difference in the expansion region between the exit of the ion source and the first quadrupole can be increased to produce (additional) fragment ions from energetic collisions in this high-pressure region, up-front CID. The resultant fragment ions can then be mass-selected and decomposed by collisions (5-25 eV) in the second quadrupole $\left(\mathrm{MS}^{3}\right)$ as discussed above. Consequently, one can achieve extensive dissociation of protonated bases and other fragment ions from the protonated antiviral agents.

The combination of up-front CID and mass sorted CID $\left(\mathrm{MS}^{3}\right)$ was useful in determining origins of some fragment ions in the CID mass spectra. Where applicable, fragmentation pathways were verified by multiple stages of de- 
Table 1. Structures and ionization constants of antiviral agents

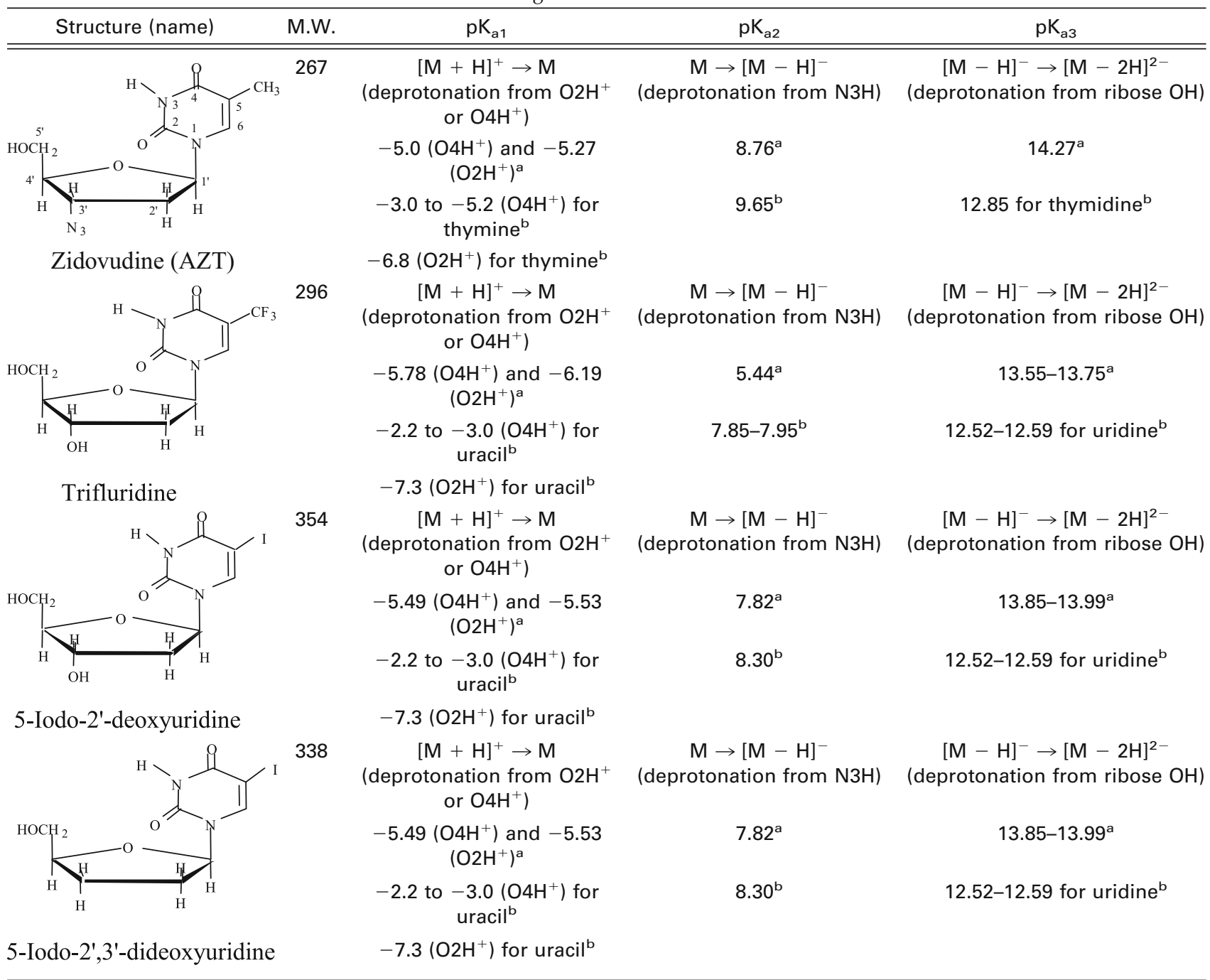

Unless otherwise noted, $\mathrm{pK}_{\mathrm{a} 1}, \mathrm{pK}_{\mathrm{a} 2}$ and $\mathrm{pK}_{\mathrm{a} 3}$ values refer to the corresponding antiviral agent as drawn.

avalue calculated by ZPARC $\mathrm{pK}_{\mathrm{a}}$ program (ref. 48).

biterature value (ref. 42-47).

composition, $\mathrm{MS}^{\mathrm{N}}$, using an ion trap, Finnigan LCQ (Finnigan MAT, San Jose, CA). In most cases mechanistic proposals were made with the proton located at a specific site. The assignments of structures to fragment ions in the CID spectra of $[\mathrm{M}+\mathrm{H}]^{+}$and $[\mathrm{M}-\mathrm{H}]^{-}$ions were aided by the mass shifts from the corresponding CID spectra of the deuterated antiviral agents.

\section{Results and Discussion}

\section{Positive Ions}

The structures, molecular weights, and $\mathrm{pK}_{\mathrm{a}}$ values for the antiviral agents with the numbering system are given in Table 1. Some of the $\mathrm{pK}_{\mathrm{a}}$ values are from the literature [42-47] and others were calculated with the ZPARC $\mathrm{pK}_{\mathrm{a}}$ program [48].

The low-energy ( $5 \mathrm{eV}$ ) CID mass spectra of these four antiviral agents are given in Figure 1. Except for AZT, these relatively weak basic pyrimidine derivatives show the sugar ion, $[\mathrm{S}]^{+}$, as the major product ion at $5 \mathrm{eV}$ collision energy with much smaller amounts of the protonated base; therefore, formation of the sugar ion is the lowest energy decomposition reaction. The presence of an electron donating methyl group in the pyrimidine ring and the absence of $\mathrm{OH}$ group at C-2' and C-3' in the sugar moiety of AZT, however, may increase the proton affinity of the base and enhance the abundance of protonated base. These observations suggest that the thymine base of AZT, not the sugar, is protonated. Replacement of both hydroxyl groups with hydrogen atoms at positions $2^{\prime}$ and $3^{\prime}$ of the sugar ring has been reported to enhance the basicity of a given nucleoside and might favor protonation of the base [49].

The proton affinities (PAs) or gas-phase basicities of these antiviral agents are not known. However, the proton affinities of thymine and uracil $2^{\prime}, 3^{\prime}$-dideoxyribonucleoside were calculated to be $\sim 955 \mathrm{~kJ} / \mathrm{mol}$ and $946 \mathrm{~kJ} / \mathrm{mol}$, respectively [49]. Kinetic method and ab 

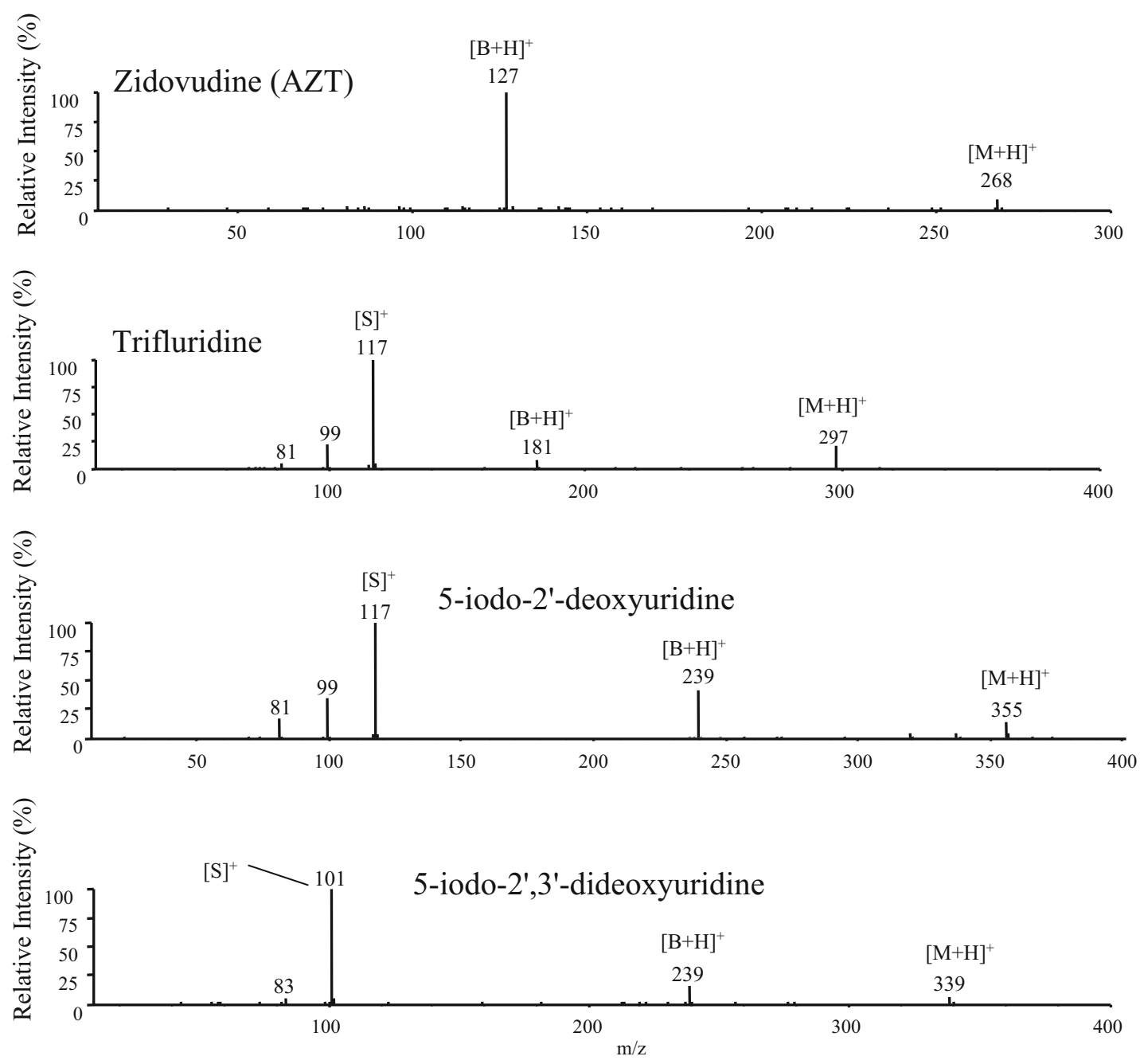

Figure 1. CID product ion spectra of $[\mathrm{M}+\mathrm{H}]^{+}$ions of pyrimidine antivirals at low collision energy (CE) of $5 \mathrm{eV}$.

initio calculations were also used to determine the proton affinities of nucleic acid molecules [50-52].

The experimental conditions (pressure and collision energy) were essentially the same for these four compounds; therefore, the stabilities of the protonated antiviral agents are comparable. Most of the CID experiments were done on $[\mathrm{M}+\mathrm{H}]^{+}$ions sprayed from solutions of $1 \% \mathrm{CH}_{3} \mathrm{COOH}$ in $1 / 1 \mathrm{CH}_{3} \mathrm{OH} / \mathrm{H}_{2} \mathrm{O}$.

Protonated pyrimidine antiviral agents dissociate through rearrangement decompositions of base-protonated $[\mathrm{M}+\mathrm{H}]^{+}$ions by cleavage of the glycosidic bonds to give the protonated bases. In addition to minor fragmentation pathways, protonated pyrimidine bases dissociate through three common pathways: (1) elimination of $\mathrm{NH}_{3}$, (2) loss of $\mathrm{H}_{2} \mathrm{O}$, and (3) elimination of NHCO.

\section{Collision-Induced Dissociation of Protonated Zidovudine (AZT)}

Figure 2 shows a comparison of spectra of $[\mathrm{M}+\mathrm{H}]^{+}$ ions from AZT and the $\left[\mathrm{M}\left(\mathrm{d}_{2}\right)+\mathrm{D}\right]^{+}$analog produced by gas-phase exchange using $\mathrm{ND}_{3}$ as the nebulizer gas.
Figure 2a shows superimposed spectra in the molecular weight region from two sets of experiments on a single loop injection of $\mathrm{AZT}$, one with $\mathrm{N}_{2}$ and the other with $\mathrm{ND}_{3}$ as the nebulizer gas. The shift from $m / z 268$ to 271 is consistent with the number of acidic protons present in the molecule.

The CID spectra ( $25 \mathrm{eV}$ collision energy) of $[\mathrm{M}+\mathrm{H}]^{+}$ at $m / z 268$ and of $\left[\mathrm{M}\left(\mathrm{d}_{2}\right)+\mathrm{D}\right]^{+}$at $m / z 271$ are shown in Figure $2 \mathrm{~b}$. The protonated thymine ion at $m / z 127$ is shifted almost exclusively to $\mathrm{m} / \mathrm{z} 130$. The minor product at $\mathrm{m} / \mathrm{z}$ 142/143 (undeuterated/deuterated) contains one exchangeable $\mathrm{H} / \mathrm{D}$ atom and is presumably the sugar ion.

Figure $2 \mathrm{c}$ shows the CID spectra of protonated thymine at $\mathrm{m} / \mathrm{z} 127$ and the deuterium-exchanged species at $\mathrm{m} / \mathrm{z} 130$ obtained by up-front CID of ions at $\mathrm{m} / \mathrm{z}$ 268/271. Protonated thymine loses $\mathrm{H}_{2} \mathrm{O}$ or $\mathrm{NH}_{3}$, as indicated by the abundant fragment ions at $\mathrm{m} / \mathrm{z} 109$ or 110 from $\mathrm{m} / \mathrm{z} 127$ and abundant ions at 110 from the fully exchanged species at $m / z 130$. Comparison of the CID spectra of undeuterated/deuterated ions at 127/ 130 (Figure 2c) and 110/110 (Figure 2d) allows the separation of consecutive and competing decomposi- 
tions from protonated thymine. Expulsion of $\mathrm{HNCO} /$ DNCO from protonated thymine at $m / z 127 / 130$, perhaps by a Retro Diels Alder reaction (RDA), produces the prominent fragment ions at $\mathrm{m} / \mathrm{z}$ 84/86 (not observed in the CID spectrum of ions at $m / z 110$ in Figure 2d). Decarbonylation of these ions gives fragment ions at $\mathrm{m} / \mathrm{z} 56 / 58$. Both the deammoniated fragment ions $(\mathrm{m} / \mathrm{z}$ $110 / 110)$ and the water loss fragment ion $(\mathrm{m} / z$ 109/110) lose $\mathrm{CO}$, giving rise to fragment ions at $m / z 82 / 82$ and $m / z 81 / 82$, respectively. A second decarbonylation follows from $m / z 82 / 82$, giving rise to fragment ion at $m / z$ $54 / 54$. Finally, protonated isocyanic acid appears as a minor fragment ion at $\mathrm{m} / \mathrm{z} 44 / 46$ from protonated thymine at $m / z 127 / 130$.

For AZT with a thymine base, the inductive effects of a methyl group (electron donating group) make the adjacent carbonyl group $(\mathrm{C}=\mathrm{O} 4)$ a likely site of protonation. Protonation at the N1 and N3 sites are unfavorable processes for both thymine and uracil and the most stable protonated forms of these two pyrimidine bases are those protonated at the anti-(N3)O4 position [53]. The $\mathrm{O} 4$ of thymine nucleosides has been reported to be the site of protonation $[42,54]$. The basicity of the two carbonyl groups in uracil derivatives has been determined and results indicate that the $\mathrm{C}=\mathrm{O} 4$ is more basic than the $\mathrm{C}=\mathrm{O} 2$ [55].

The collision-induced dissociations of protonated uracil and its derivatives have been studied by tandem mass spectrometry using compounds selectively labeled with ${ }^{2} \mathrm{H},{ }^{13} \mathrm{C},{ }^{15} \mathrm{~N}$, and ${ }^{18} \mathrm{O}$ [18]. Similar to the mechanism proposed earlier for the decomposition of protonated uracil [18], the collisionally induced dissociations of protonated thymine appear to proceed by three principle pathways: (1) elimination of $\mathrm{NH}_{3}$, (2) loss of water, and (3) elimination of isocyanic acid (HNCO). Additional dissociation products are formed as a result of subsequent losses of $\mathrm{CO}$ from the three principal decomposition products. A proposed mechanism for the formation of the protonated isocyanic acid, loss of $\mathrm{NH}_{3}$ and $\mathrm{H}_{2} \mathrm{O}$ from the $\mathrm{C}=\mathrm{O} 4$ protonated species as well as subsequent losses of $\mathrm{CO}$ is shown in Scheme 1.

\section{Collision-Induced Dissociation of Protonated Trifluridine}

The shift from $\mathrm{m} / \mathrm{z} 297$ for $[\mathrm{M}+\mathrm{H}]^{+}$of trifluridine to 301 for the fully exchanged species $\left[\mathrm{M}\left(\mathrm{d}_{3}\right)+\mathrm{D}\right]^{+}$is consistent with the acidic protons present in the molecule, all of the amine and hydroxyl hydrogens. The CID spectra of ions at 297 and 301 at collision energy of $25 \mathrm{eV}$ show that the protonated trifluoromethyluracil ion at $m / z 181$ is shifted almost exclusively to $\mathrm{m} / \mathrm{z} 184$. Formation of protonated trifluoromethyluracil seems to require protonation on the base with intramolecular hydrogen transfer from one of the hydroxyl groups of the sugar and heterolytic cleavage of the N-glycosidic bond.

The CID spectra of the ionic species at $m / z 181$ and the fully exchanged species at $m / z 184$ were obtained by up-front CID of $[\mathrm{M}+\mathrm{H}]^{+}$at $m / z 297$ and $\left[\mathrm{M}\left(\mathrm{d}_{3}\right)+\right.$ $\mathrm{D}^{+}$at 301 followed by tandem CID are shown in Figure 3. The dissociation reactions of protonated trifluoromethyluracil begin with elimination of $\mathrm{HF} / \mathrm{DF}$ to give $(\mathrm{m} / \mathrm{z} 161 / 163)$ followed by expulsion of $\mathrm{HNCO} / \mathrm{DNCO}$ to give $(\mathrm{m} / \mathrm{z} 118 / 119)$ with the subsequent loss of HCN/DCN to give $(m / z$ 91/91). These dissociation reactions are interpreted in terms of ring opening of the trifluoromethyluracil at likely sites of protonation after collisional activation of [M $+\mathrm{H}]^{+}$. A mechanism for the decompositions of protonated trifluoromethyluracil is proposed in Scheme 2. The fragmentation pathways of $2^{\prime}$-deoxycytidine, 2' -deoxyuridine, and their oxidatively damaged derivatives were investigated by isotope labeling and multiple stage Mass spectrometry and similar mechanism for the loss of $\mathrm{NH}_{3}, \mathrm{HCN}, \mathrm{H}_{2} \mathrm{O}$ and HNCO were proposed [56, 57]

Sugar ions are major ions in the low-energy CID spectrum of trifluridine, Figure 1. The fragment ions at $m / z 117,99,81$, and their corresponding deuterated fragment ions at $m / z 119,100$, and 81 are sugar derived ions since these ions do not occur in the CID spectra of the base ions at $m / z 181 / 184$. The low-energy decomposition path for the sugar ions at $m / z 117 / 119$ produces ions at $m / z 99 / 100$ and at $m / z 81 / 81$ from loss of water. At higher collision energies (not shown) the sugar ions at $m / z 117 / 119$ also lose water and then formaldehyde and acetylene to give fragment ions at $\mathrm{m} / \mathrm{z} 99 / 99, \mathrm{~m} / \mathrm{z}$ $69 / 69$, and $43 / 43$.

\section{Collision-Induced Dissociation of Protonated 5-Iodo-2', 3'-Dideoxyuridine}

The CID spectra of $[\mathrm{M}+\mathrm{H}]^{+}$of 5-iodo-2', $3^{\prime}-$ dideoxyuridine at $m / z 339$ and of $\left[\mathrm{M}\left(\mathrm{d}_{2}\right)+\mathrm{D}\right]^{+}$at $m / z$ 342 (not shown) at collision energy of $25 \mathrm{eV}$ show that protonated 5-iodouracil at $m / z 239$ is shifted almost exclusively to $\mathrm{m} / \mathrm{z} 242$.

A comparison of the CID spectrum of the ions at $\mathrm{m} / \mathrm{z}$ 239 and at $m / z 242$ (not shown) shows the loss of ammonia to form fragment ions at $m / z 222 / 222$ and loss of water to form ions at $m / z 221 / 222$. Decarbonylation occurs from both the deammoniated fragment ion $(\mathrm{m} / \mathrm{z} 222 / 222)$ and from the dehydrated fragment ion $(\mathrm{m} / \mathrm{z} 221 / 222)$, giving rise to fragment ions at $m / z 194 / 194$ and $m / z$ 193/194, respectively. Expulsion of $\mathrm{HNCO} / \mathrm{DNCO}$, perhaps by RDA mechanism from protonated 5-iodouracil at $\mathrm{m} / \mathrm{z}$ 239/242, produces prominent fragment ions at $m / z$ 196/ 198. A second decarbonylation occurs for both $\mathrm{m} / \mathrm{z}$ 194/ 194 and $m / z$ 196/198 giving rise to fragment ions at $\mathrm{m} / \mathrm{z}$ $166 / 166$ and $m / z$ 168/170, respectively.

A prominent fragment ion at $m / z 112$ in the $25 \mathrm{eV}$ CID spectrum of protonated 5-iodouracil at $m / z 239$ is shifted to $m / z 115$ from the collisionally induced decomposition of the fully exchanged species at $m / z 242$. All of the exchanged hydrogens are retained. This ion is due to the loss of an iodine atom from the protonated 


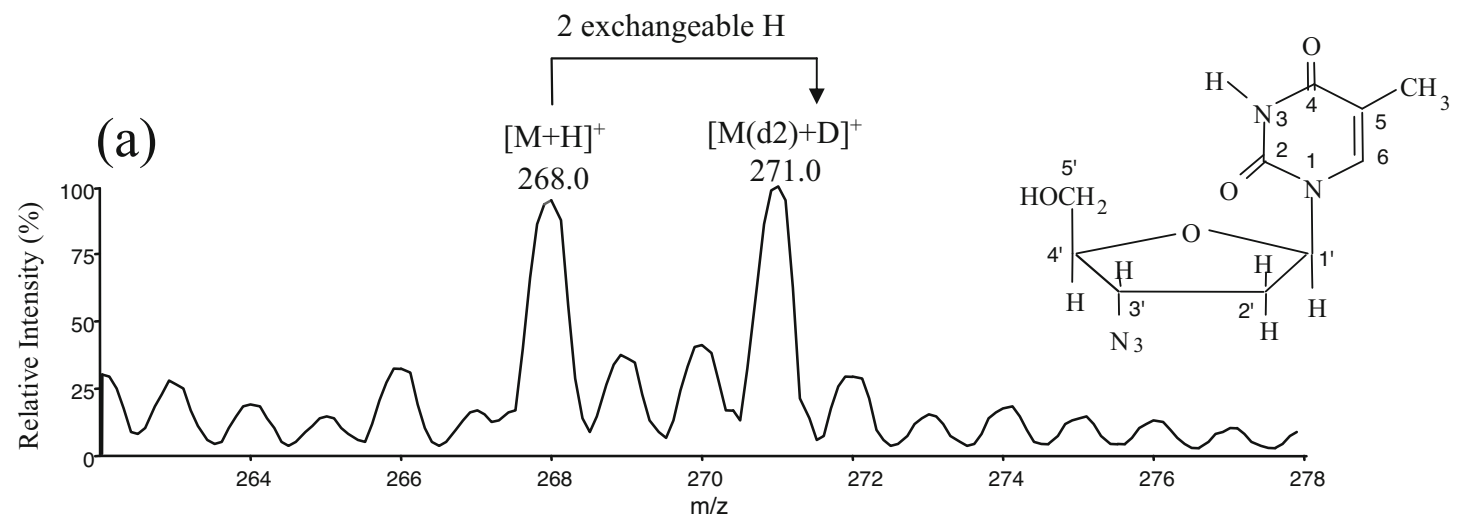

(b)

$[\mathrm{B}+\mathrm{H}]^{+}$
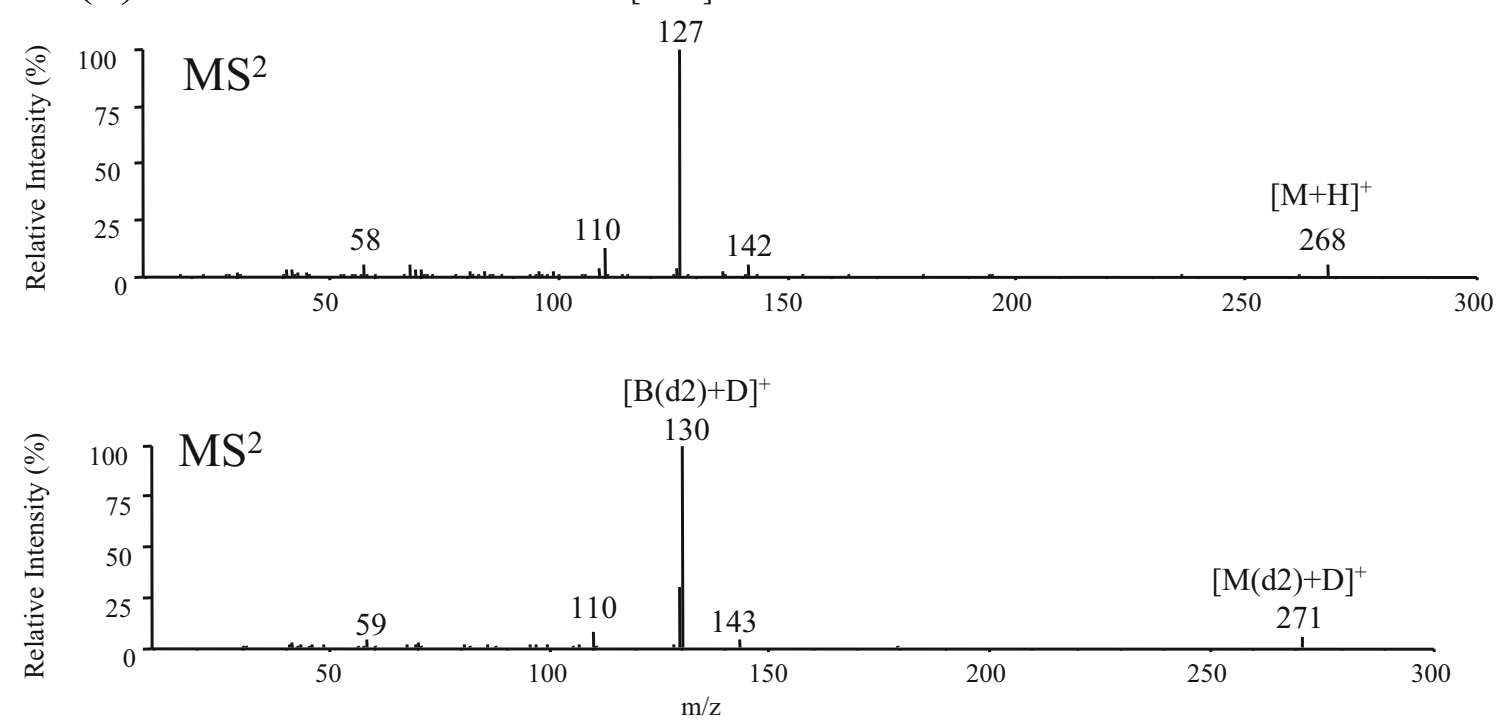

Figure 2. Positive ion ESI mass spectra of zidovudine (AZT, MW = 267): (a) total ion current showing both $[\mathrm{M}+\mathrm{H}]^{+}$and $[\mathrm{M}(\mathrm{d} 2)+\mathrm{D}]^{+}$in a single experiment (b) CID product ion spectra (MS2) of $[\mathrm{M}+\mathrm{H}]^{+}$at $m / z 268$ and the fully exchanged $[\mathrm{M}(\mathrm{d} 2)+\mathrm{D}]^{+}$at $m / z 271$ at a $\mathrm{CE}$ of $25 \mathrm{eV}$ (c) $\mathrm{MS}^{3}$ generated by up-front CID of protonated base at $\mathrm{m} / \mathrm{z} 127$ and its corresponding deuterated fragment ion at $\mathrm{m} / \mathrm{z} 130$ (d) $\mathrm{MS}^{3}$ generated by up-front CID of fragment ion at $\mathrm{m} / \mathrm{z} 110$ and its corresponding deuterated fragment ion at $m / z$ 110. Deuteration was achieved by nebulizer $\mathrm{ND}_{3}$ gas-phase $\mathrm{H} / \mathrm{D}$ exchange method. MS and MS $^{2}$ experiments were performed on a SCIEX API-III-plus triple quadrupole mass spectrometer.

5-iodouracil. Three competitive decomposition pathways are derived from the fragment ion at $m / z$ 112/115: (1) elimination of $\mathrm{HNCO} / \mathrm{DNCO}$ followed by decarbonylation to produce fragment ions at $\mathrm{m} / \mathrm{z} 69 / 71$ and $\mathrm{m} / \mathrm{z} 41 / 43$, respectively, (2) loss of $\mathrm{CO}$ to produce fragment ion at $m / z 84 / 87$, and (3) loss of $\mathrm{H}_{2} \mathrm{O} / \mathrm{D}_{2} \mathrm{O}$ to give rise to fragment ion at $\mathrm{m} / \mathrm{z}$ 94/95.

Finally, protonated isocyanic acid appears as a major fragment ion at $m / z 44 / 46$, which can be formed directly from protonated 5-iodouracil at $\mathrm{m} / \mathrm{z} 239 / 242$.

Sugar ions are abundant in the CID spectrum of 5 -iodo-2', $3^{\prime}$-dideoxyuridine (Figure 1 at $5 \mathrm{eV}$ and also at $25 \mathrm{eV}$, not shown). The fragment ions at $\mathrm{m} / \mathrm{z} 101,83$, $73,57,55,43$, and their corresponding deuterated fragment ions are sugar derived ions since these ions do not occur in the CID spectra of the protonated base. Two competitive decomposition pathways are observed for the sugar ion [S] ${ }^{+}$at $m / z$ 101/102 One decomposition pathway produces the fragment ions at $\mathrm{m} / \mathrm{z} 73 / 74$ and $43 / 44$ by elimination of neutral ethylene followed by expulsion of neutral formaldehyde. The other decomposition pathway is the loss of $\mathrm{H}_{2} \mathrm{O} / \mathrm{HDO}$ to produce fragment ion at $\mathrm{m} / \mathrm{z} 83 / 84$.

The collisionally induced dissociation reactions of protonated 5-iodouracil, like the other protonated pyrimidines, are (1) elimination of $\mathrm{NH}_{3}$, (2) loss of $\mathrm{H}_{2} \mathrm{O}$ or (3) elimination of HNCO. Subsequent losses of $\mathrm{CO}$ are observed from the three primary decomposition products. Most collisionally induced decompositions involve the loss of small stable neutral molecules; however, protonated 5-iodouracil loses an iodine atom to give the uracil ion, $m / z$ 112. The CID spectrum of uracil contains products from loss of $\mathrm{H}_{2} \mathrm{O}, \mathrm{CO}$, and $\mathrm{HNCO}$. 
(c)
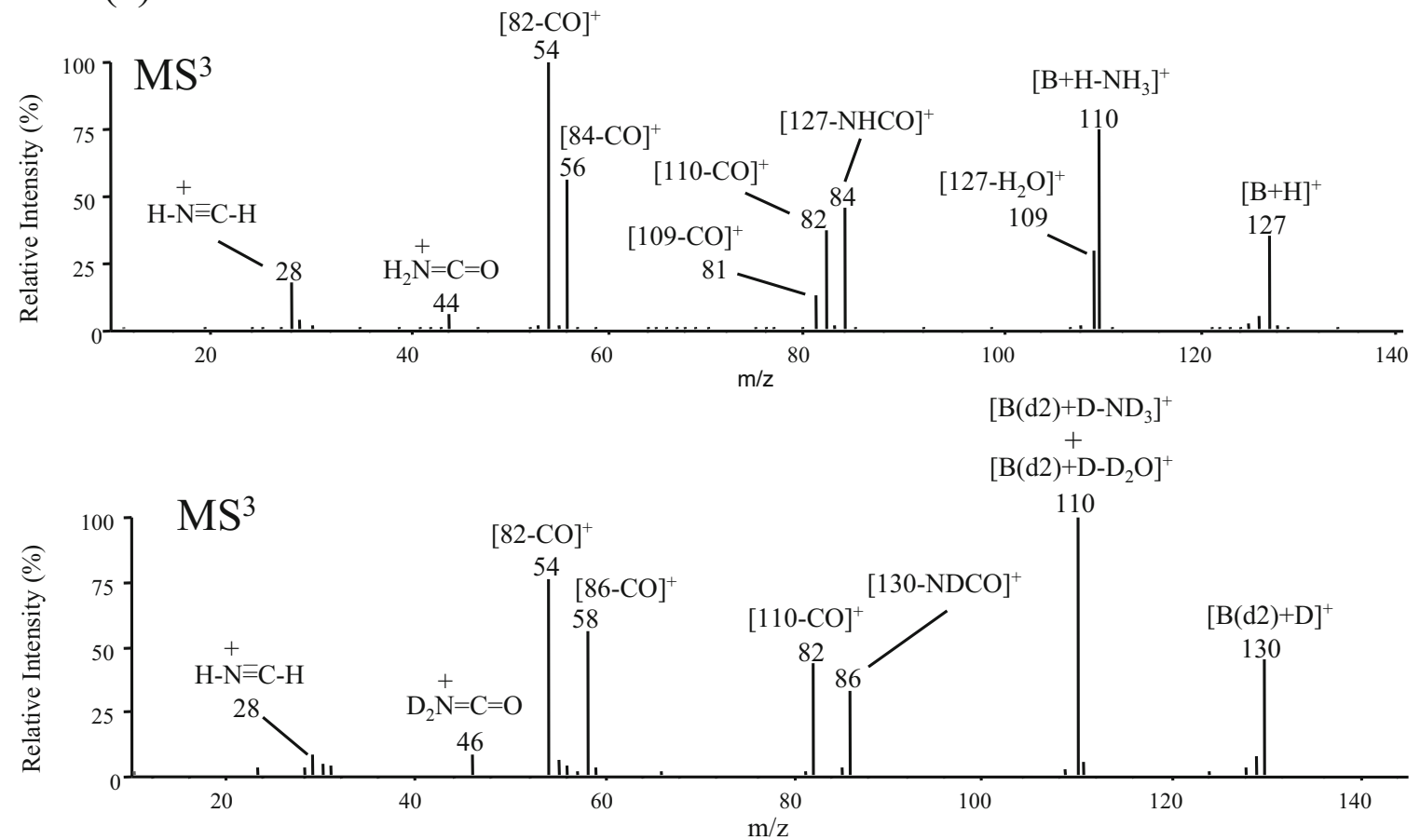

(d)
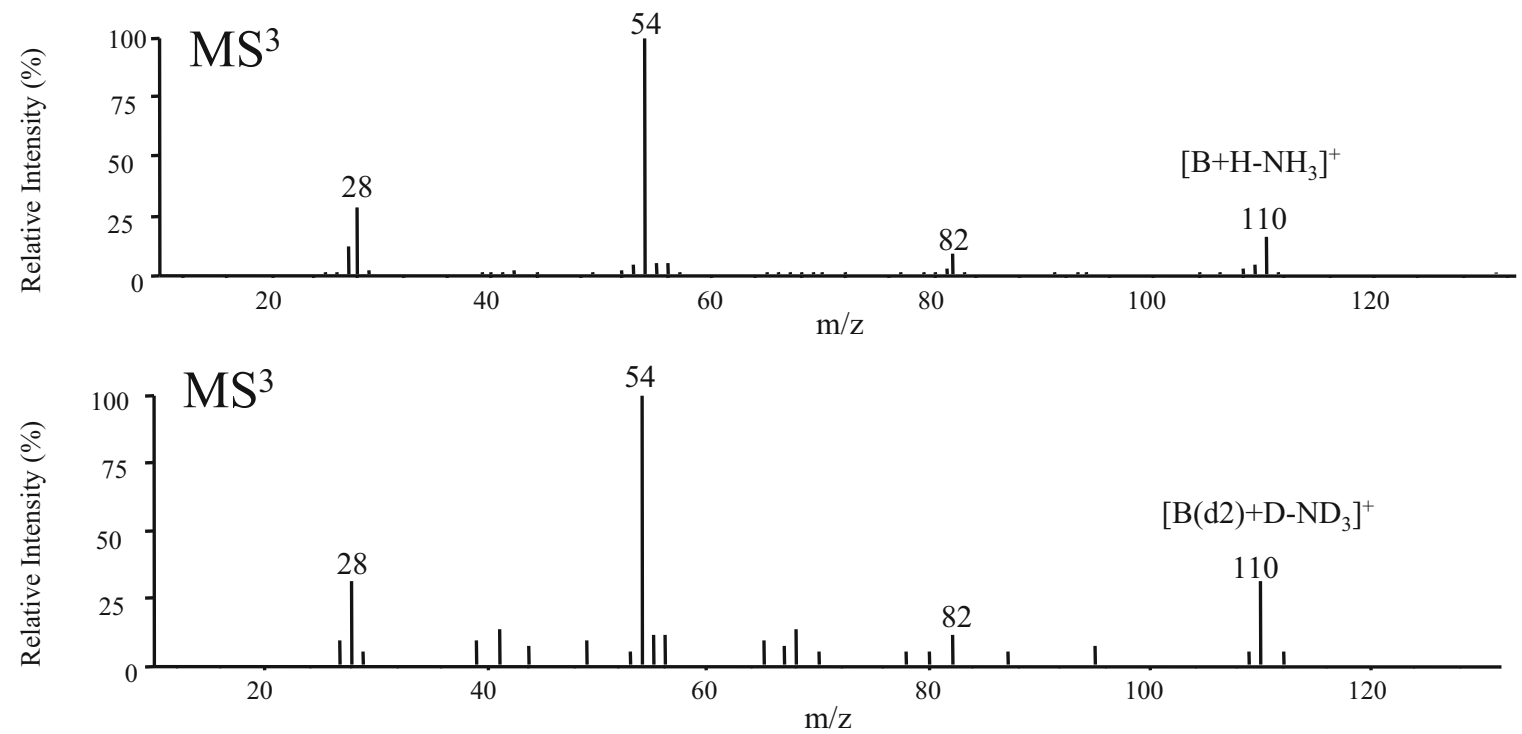

Figure 2. Continued.

\section{Collision-Induced Dissociation of Protonated 5-Iodo-2'-Deoxyuridine}

The CID spectra of $[\mathrm{M}+\mathrm{H}]^{+}$of 5-iodo-2'-dideoxyuri-

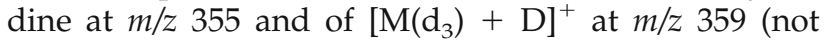
shown) at collision energy of $25 \mathrm{eV}$ show that protonated 5-iodouracil at $m / z 239$ is shifted almost exclusively to $m / z 242$. The CID spectra of the ionic species at $m / z 239$ and the fully exchanged species at $\mathrm{m} / \mathrm{z} 242$ obtained by up-front CID followed by tandem CID are the same as those presented and discussed in detail in the previous section (CID of protonated 5-iodo-2' $3^{\prime}$-dideoxyuridine).
Sugar ions are exhibited in significant abundance in the CID spectrum of protonated 5-iodo-2'-deoxyuridine and were identical to those obtained in the CID spectrum of trifluridine.

Table 2 shows the principal positive ion dissociation products for these antiviral agents for the undeuterated and deuterated species. These assignments were made from the combination of up-front CID and tandem CID mass spectra on undeuterated and deuterated ions. All protonated pyrimidine derivatives dissociate primarily to give the protonated bases $[\mathrm{B}+\mathrm{H}]^{+}$. 


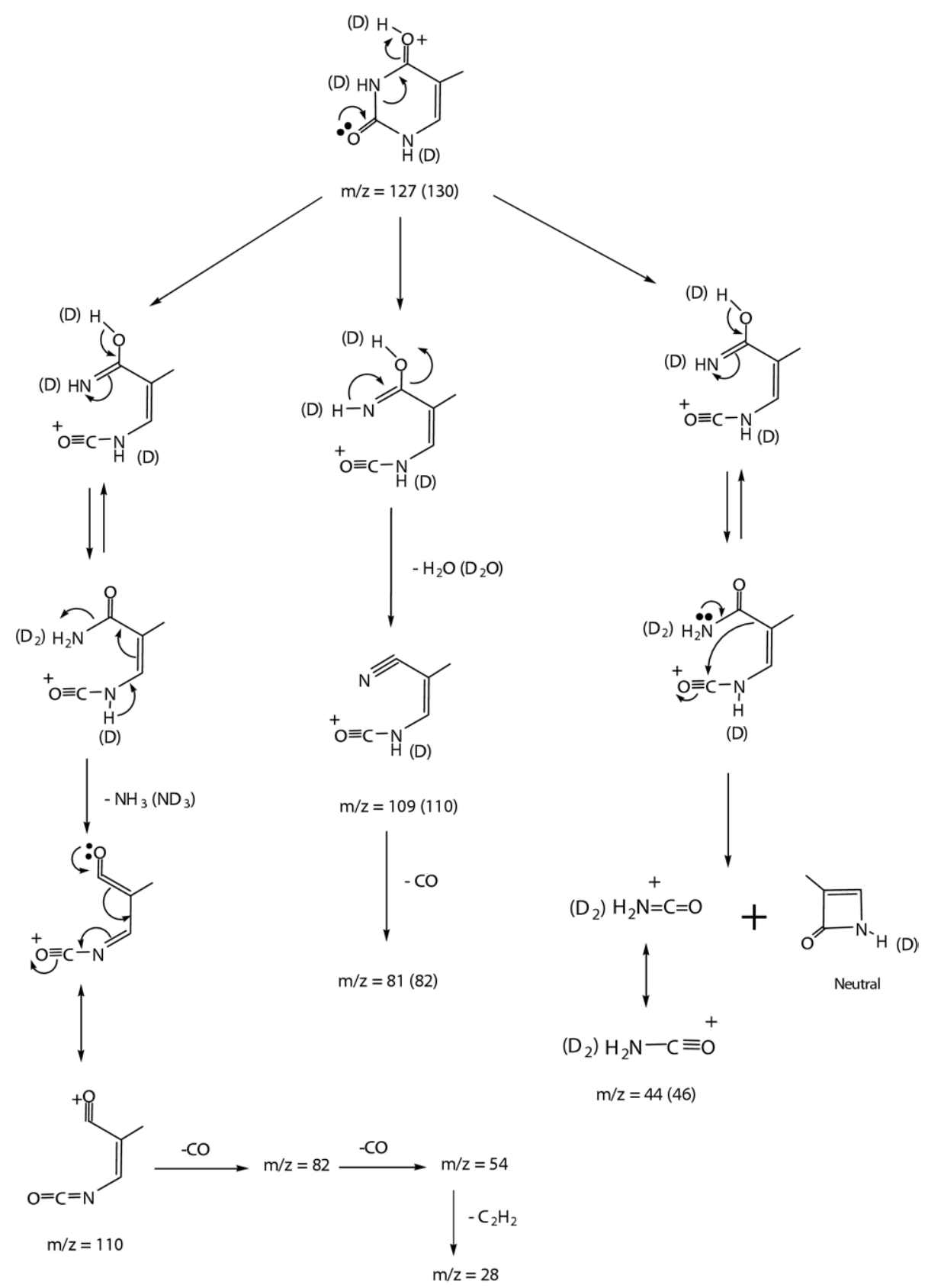

Scheme 1. Proposed CID fragmentation mechanisms for the major fragment ions from protonated base of zidovudine (AZT) at $\mathrm{m} / \mathrm{z} 127$ determined from both $\mathrm{H} / \mathrm{D}$ exchange patterns and $\mathrm{MS}^{3}$ experiments assuming protonation at $\mathrm{C}=\mathrm{O} 4$. Numbers in parentheses refer to deuterated fragment ions.

$\mathrm{CID}$ of $[\mathrm{B}+\mathrm{H}]^{+}$occurs mainly through elimination of $\mathrm{NH}_{3}, \mathrm{H}_{2} \mathrm{O}$, and of $\mathrm{HNCO}$. Protonated trifluoromethyluracil, however, dissociates primarily through elimination of HF followed by the loss of HNCO. Secondary dissociation products are also formed as a result of subsequent losses of $\mathrm{CO}$ from the principal decomposition pathways.

\section{Negative Ions}

The CID mass spectra of $[\mathrm{M}-\mathrm{H}]^{-}$ions of all four antiviral agents show $\mathrm{NCO}^{-}$as the principal decom- position product. A lesser amount of deprotonated base is formed from cleavage of the glycosidic bond with charge delocalization on the base. Elimination of $\mathrm{HNCO}, \mathrm{HN}_{3}, \mathrm{HF}, \mathrm{CO}$, and formation of iodide ion are minor dissociation pathways from $[\mathrm{M}-\mathrm{H}]^{-}$ions.

\section{Collision-Induced Dissociation of Deprotonated Zidooudine (AZT)}

The CID spectrum of $[\mathrm{M}-\mathrm{H}]^{-}$of AZT at $\mathrm{m} / z 266$ in Figure $4 \mathrm{a}$ is significantly more complex than the CID 

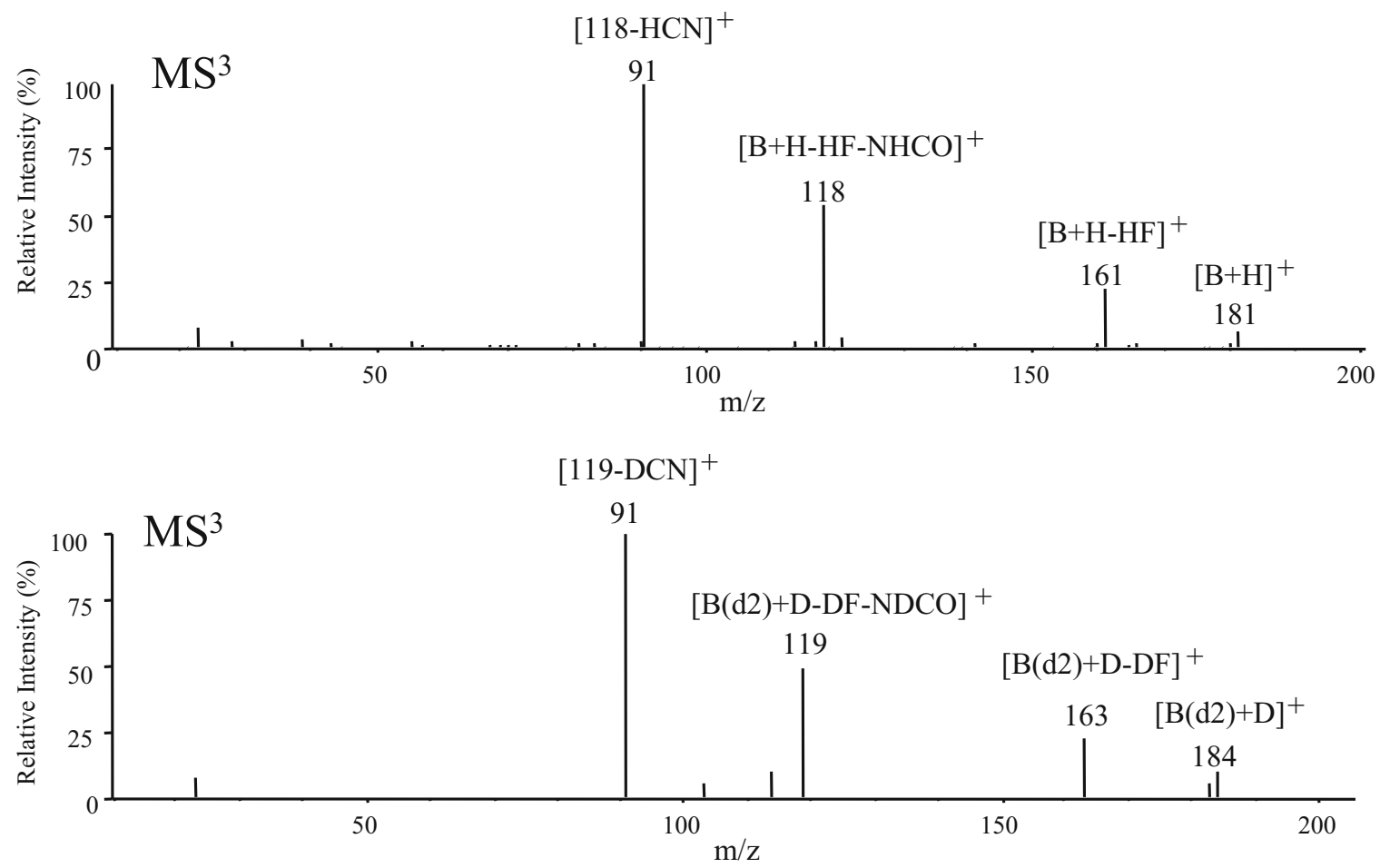

Figure 3. CID product ion spectra $\left(\mathrm{MS}^{3}\right)$ of protonated base $[\mathrm{B}+\mathrm{H}]^{+}$of trifluridine at $m / z 181$ and its corresponding deuterated fragment ion at $\mathrm{m} / z 184$.

spectrum of $[\mathrm{M}+\mathrm{H}]^{+}$of AZT at $m / z 268$ in Figure $2 \mathrm{~b}$ and contains only very small abundances of $[\mathrm{B}-\mathrm{H}]^{-}$ and essentially no sugar ions. Direct cleavage of the $\mathrm{N}$-glycosidic bond, with or without $\mathrm{H}$-transfer, is only a minor decomposition reaction for deprotonated AZT.

The only abundant low mass ion in the CID spectrum of $[\mathrm{M}-\mathrm{H}]^{-}$at 266 is $\mathrm{m} / \mathrm{z} 42$. Ions at the same $\mathrm{m} / \mathrm{z}$ value are observed in the CID spectrum of $\left[\mathrm{M}\left(\mathrm{d}_{2}\right)-\right.$ $\mathrm{D}^{-}$at $m / z 267$. The species is most probably $\mathrm{NCO}^{-}$. Ions at $\mathrm{m} / \mathrm{z} 42$ may be formed from direct decomposition of $[\mathrm{M}-\mathrm{H}]^{-}$and $\left[\mathrm{M}\left(\mathrm{d}_{2}\right)-\mathrm{D}\right]^{-}$ions, but they are also formed from the decomposition of fragment ions at $m / z$ 223/224 (Figure 4b).

The fragment ions at $\mathrm{m} / \mathrm{z} 223$ and 224 in the CID spectrum of $[\mathrm{M}-\mathrm{H}]^{-}$at 266 are shifted to $\mathrm{m} / \mathrm{z} 223,224$, and 225 in the CID spectrum of $\left[\mathrm{M}\left(\mathrm{d}_{2}\right)-\mathrm{D}\right]^{-}$at $m / z 267$, Figure 4a. The fragment ions at $m / z 224 / 225$ in the CID spectrum of deprotonated (de-deuteronated) AZT result from the loss of $\mathrm{CH}_{2} \mathrm{O}$ or $\mathrm{N}_{3}$, because no exchangeable hydrogens are lost. The ions at $m / z 223$ in the CID spectrum of $[\mathrm{M}-\mathrm{H}]^{-}$(Figure $4 \mathrm{a}$, top) are present as $m / z 223 / 224$ in the CID spectrum of $\left[\mathrm{M}\left(\mathrm{d}_{2}\right)-\mathrm{D}\right]^{-}$ (Figure $4 \mathrm{a}$, bottom). The loss of $\mathrm{HN}_{3}$ is somewhat larger than the loss of HNCO/DNCO: I(223)/I(224) 0.75. The loss of $\mathrm{HN}_{3}$ would involve the loss of a nonexchangeable hydrogen from the sugar and would give ions at $\mathrm{m} / \mathrm{z} 223$ from $\left[\mathrm{M}\left(\mathrm{d}_{2}\right)-\mathrm{D}\right]^{-}$and the loss of isocyanic acid would surely involve the exchangeable amine hydrogen and give ions at $\mathrm{m} / \mathrm{z} 224$.

The CID spectra of the ionic species at $m / z 223 / 224$ obtained by up-front CID of [M - H] $]^{-}$and $\left[\mathrm{M}\left(\mathrm{d}_{2}\right)-\right.$ $\mathrm{D}^{-}$followed by tandem CID are shown in Figure $4 \mathrm{~b}$. Loss of $\mathrm{CH}_{2} \mathrm{O}$ is observed to form low abundance ions at $\mathrm{m} / \mathrm{z}$ 193/194. A subsequent loss of $\mathrm{HNCO} /$ DNCO is also observed to give minor ions at $m / z 150$.

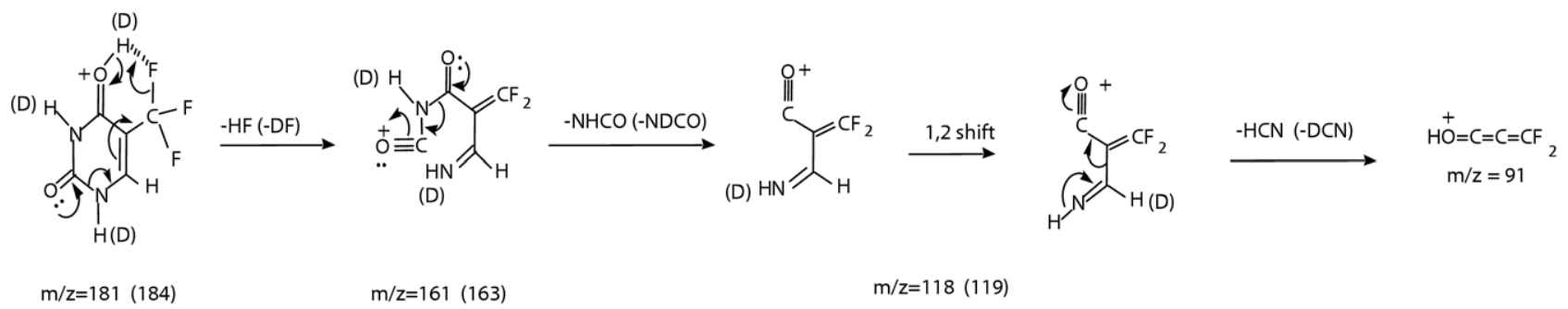

Scheme 2. Proposed CID fragmentation mechanisms of protonated base of trifluridine at $\mathrm{m} / \mathrm{z} 181$ determined from both H/D exchange patterns and $\mathrm{MS}^{3}$ experiments. Numbers in parentheses refer to deuterated fragment ions. 
Table 2. Principal dissociation products of protonated antivirals

\begin{tabular}{|c|c|c|c|}
\hline Product ion & Mass-to-charge ratio & Deuterated product ion & Deuterated mass-to-charge ratio \\
\hline \multicolumn{4}{|c|}{ zidovudine AZT $\left(\mathrm{MW}=267,[\mathrm{M}+\mathrm{H}]^{+}=268,[\mathrm{M}(\mathrm{d} 2)+\mathrm{D}]^{+}=271\right)$} \\
\hline $268-126$ & 142 & $271-128$ & 143 \\
\hline $268-141$ & 127 & $271-141$ & 130 \\
\hline $127-\mathrm{NH}_{3}$ & 110 & $130-\mathrm{ND}_{3}$ & 110 \\
\hline $127-\mathrm{H}_{2} \mathrm{O}$ & 109 & $130-\mathrm{D}_{2} \mathrm{O}$ & 110 \\
\hline $127-\mathrm{NHCO}$ & 84 & $130-\mathrm{NDCO}$ & 86 \\
\hline $110-\mathrm{CO}$ & 82 & $110-\mathrm{CO}$ & 82 \\
\hline $109-\mathrm{CO}$ & 81 & $110-\mathrm{CO}$ & 82 \\
\hline $84-\mathrm{CO}$ & 56 & $86-\mathrm{CO}$ & 58 \\
\hline $82-\mathrm{CO}$ & 54 & $82-\mathrm{CO}$ & 54 \\
\hline $\mathrm{H}_{2} \mathrm{NCO}$ & 44 & $\mathrm{D}_{2} \mathrm{NCO}$ & 46 \\
\hline $54-\mathrm{C}_{2} \mathrm{H}_{2}$ & 28 & $54-\mathrm{C}_{2} \mathrm{H}_{2}$ & 28 \\
\hline $\mathrm{C}_{2} \mathrm{HO}_{2}$ & 58 & $\mathrm{C}_{2} \mathrm{DO}_{2}^{+}$ & 59 \\
\hline \multicolumn{4}{|c|}{ trifluridine $\left(\mathrm{MW}=296,[\mathrm{M}+\mathrm{H}]^{+}=297,[\mathrm{M}(\mathrm{d} 3)+\mathrm{D}]^{+}=301\right)$} \\
\hline $297-116$ & 181 & $301-117$ & 184 \\
\hline $181-\mathrm{HF}$ & 161 & $184-\mathrm{DF}$ & 163 \\
\hline $161-\mathrm{NHCO}$ & 118 & $163-\mathrm{NDCO}$ & 119 \\
\hline $118-\mathrm{HCN}$ & 91 & $119-\mathrm{DCN}$ & 91 \\
\hline $\mathrm{C}_{5} \mathrm{H}_{9} \mathrm{O}_{3}^{+}$ & 117 & $\mathrm{C}_{5} \mathrm{D}_{2} \mathrm{H}_{7} \mathrm{O}_{3}^{+}$ & 119 \\
\hline $117-\mathrm{H}_{2} \mathrm{O}$ & 99 & $119-\mathrm{D}_{2} \mathrm{O} / 119-\mathrm{HDO}$ & $99 / 100$ \\
\hline $99-\mathrm{H}_{2} \mathrm{O}$ & 81 & $99-\mathrm{H}_{2} \mathrm{O} / 100-\mathrm{HDO}$ & 81 \\
\hline $\mathrm{C}_{3} \mathrm{H}_{5} \mathrm{O}_{2}^{+}$ & 73 & $\mathrm{C}_{3} \mathrm{H}_{4} \mathrm{DO}_{2}^{+}$ & 74 \\
\hline $\mathrm{C}_{2} \mathrm{H}_{5} \mathrm{O}^{+}$ & 69 & $\mathrm{C}_{2} \mathrm{H}_{5} \mathrm{O}^{+}$ & 69 \\
\hline $\mathrm{C}_{3} \mathrm{H}_{5} \mathrm{O}^{+}$ & 57 & $\mathrm{C}_{3} \mathrm{H}_{4} \mathrm{DO}^{+}$ & 58 \\
\hline $\mathrm{C}_{2} \mathrm{H}_{3} \mathrm{O}^{+}$ & 43 & $\mathrm{C}_{2} \mathrm{H}_{3} \mathrm{O}^{+}$ & 43 \\
\hline \multicolumn{4}{|c|}{ 5-iodo-2'-deoxyuridine $\left(\mathrm{MW}=354,[\mathrm{M}+\mathrm{H}]^{+}=355,[\mathrm{M}(\mathrm{d} 3)+\mathrm{D}]^{+}=359\right)$} \\
\hline $355-116$ & 239 & $359-117$ & 242 \\
\hline $239-\mathrm{NH}_{3}$ & 222 & $242-\mathrm{ND}_{3}$ & 222 \\
\hline $239-\mathrm{H}_{2} \mathrm{O}$ & 221 & $242-\mathrm{D}_{2} \mathrm{O}$ & 222 \\
\hline $239-\mathrm{HNCO}$ & 196 & $242-\mathrm{DNCO}$ & 198 \\
\hline $222-\mathrm{CO}$ & 194 & $222-\mathrm{CO}$ & 194 \\
\hline $221-\mathrm{CO}$ & 193 & $222-\mathrm{CO}$ & 194 \\
\hline $196-\mathrm{CO}$ & 168 & $198-\mathrm{CO}$ & 170 \\
\hline $194-\mathrm{CO}$ & 166 & $194-\mathrm{CO}$ & 166 \\
\hline $239-1$ & 112 & $242-1$ & 115 \\
\hline $112-\mathrm{CO}$ & 84 & $115-\mathrm{CO}$ & 87 \\
\hline $112-\mathrm{HNCO}$ & 69 & 115 - DNCO & 71 \\
\hline $69-\mathrm{CO}$ & 41 & $71-\mathrm{CO}$ & 43 \\
\hline $\mathrm{H}_{2} \mathrm{NCO}^{+}$ & 44 & $\mathrm{D}_{2} \mathrm{NCO}^{+}$ & 46 \\
\hline $\mathrm{C}_{5} \mathrm{H}_{9} \mathrm{O}_{3}^{+}$ & 117 & $\mathrm{C}_{5} \mathrm{D}_{2} \mathrm{H}_{7} \mathrm{O}_{3}^{+}$ & 119 \\
\hline $117-\mathrm{H}_{2} \mathrm{O}$ & 99 & $119-\mathrm{D}_{2} \mathrm{O} / 119-\mathrm{HDO}$ & $99 / 100$ \\
\hline $99-\mathrm{H}_{2} \mathrm{O}$ & 81 & $99-\mathrm{H}_{2} \mathrm{O} / 100-\mathrm{HDO}$ & 81 \\
\hline $\mathrm{C}_{3} \mathrm{H}_{5} \mathrm{O}_{2}^{+}$ & 73 & $\mathrm{C}_{3} \mathrm{H}_{4} \mathrm{DO}_{2}^{+}$ & 74 \\
\hline $\mathrm{C}_{2} \mathrm{H}_{5} \mathrm{O}^{+}$ & 69 & $\mathrm{C}_{2} \mathrm{H}_{5} \mathrm{O}^{+}$ & 69 \\
\hline $\mathrm{C}_{3} \mathrm{H}_{5} \mathrm{O}^{+}$ & 57 & $\mathrm{C}_{3} \mathrm{H}_{4} \mathrm{DO}^{+}$ & 58 \\
\hline $\mathrm{C}_{2} \mathrm{H}_{3} \mathrm{O}^{+}$ & 43 & $\mathrm{C}_{2} \mathrm{H}_{3} \mathrm{O}^{+}$ & 43 \\
\hline \multicolumn{4}{|c|}{ 5-iodo-2 ${ }^{\prime}, 3^{\prime}$-dideoxyuridine $\left(\mathrm{MW}=338,[\mathrm{M}+\mathrm{H}]^{+}=339,[\mathrm{M}(\mathrm{d} 2)+\mathrm{D}]^{+}=342\right)$} \\
\hline $339-100$ & 239 & $342-100$ & 242 \\
\hline $239-\mathrm{NH}_{3}$ & 222 & $242-\mathrm{ND}_{3}$ & 222 \\
\hline $239-\mathrm{H}_{2} \mathrm{O}$ & 221 & $242-\mathrm{D}_{2} \mathrm{O}$ & 222 \\
\hline $239-\mathrm{HNCO}$ & 196 & $242-\mathrm{DNCO}$ & 198 \\
\hline $222-\mathrm{CO}$ & 194 & $222-\mathrm{CO}$ & 194 \\
\hline $221-\mathrm{CO}$ & 193 & $222-\mathrm{CO}$ & 194 \\
\hline $196-\mathrm{CO}$ & 168 & $198-\mathrm{CO}$ & 170 \\
\hline $194-\mathrm{CO}$ & 166 & $194-\mathrm{CO}$ & 166 \\
\hline $239-1$ & 112 & $242-1$ & 115 \\
\hline $112-\mathrm{CO}$ & 84 & $115-\mathrm{CO}$ & 87 \\
\hline 112 - HNCO & 69 & 115 - DNCO & 71 \\
\hline $69-\mathrm{CO}$ & 41 & $71-\mathrm{CO}$ & 43 \\
\hline $\mathrm{H}_{2} \mathrm{NCO}^{+}$ & 44 & $\mathrm{D}_{2} \mathrm{NCO}^{+}$ & 46 \\
\hline $\mathrm{C}_{5} \mathrm{H}_{9} \mathrm{O}_{2}^{+}$ & 101 & $\mathrm{C}_{5} \mathrm{DH}_{8} \mathrm{O}_{2}{ }^{+}$ & 102 \\
\hline $101-\mathrm{H}_{2} \mathrm{O}$ & 83 & 102 - HDO & 83 \\
\hline $\mathrm{C}_{3} \mathrm{H}_{5} \mathrm{O}_{2}^{+}$ & 73 & $\mathrm{C}_{3} \mathrm{H}_{4} \mathrm{DO}_{2}^{+}$ & 74 \\
\hline $\mathrm{C}_{3} \mathrm{H}_{5} \mathrm{O}^{+}$ & 57 & $\mathrm{C}_{3} \mathrm{H}_{4} \mathrm{DO}^{+}$ & 58 \\
\hline $\mathrm{C}_{3} \mathrm{H}_{3} \mathrm{O}^{+}$ & 55 & $\mathrm{C}_{3 \mathrm{D}} \mathrm{H}_{2} \mathrm{O}^{+}$ & 56 \\
\hline $\mathrm{C}_{2} \mathrm{H}_{3} \mathrm{O}^{+}$ & 43 & $\mathrm{C}_{2} \mathrm{H}_{3} \mathrm{O}^{+}$ & 43 \\
\hline
\end{tabular}



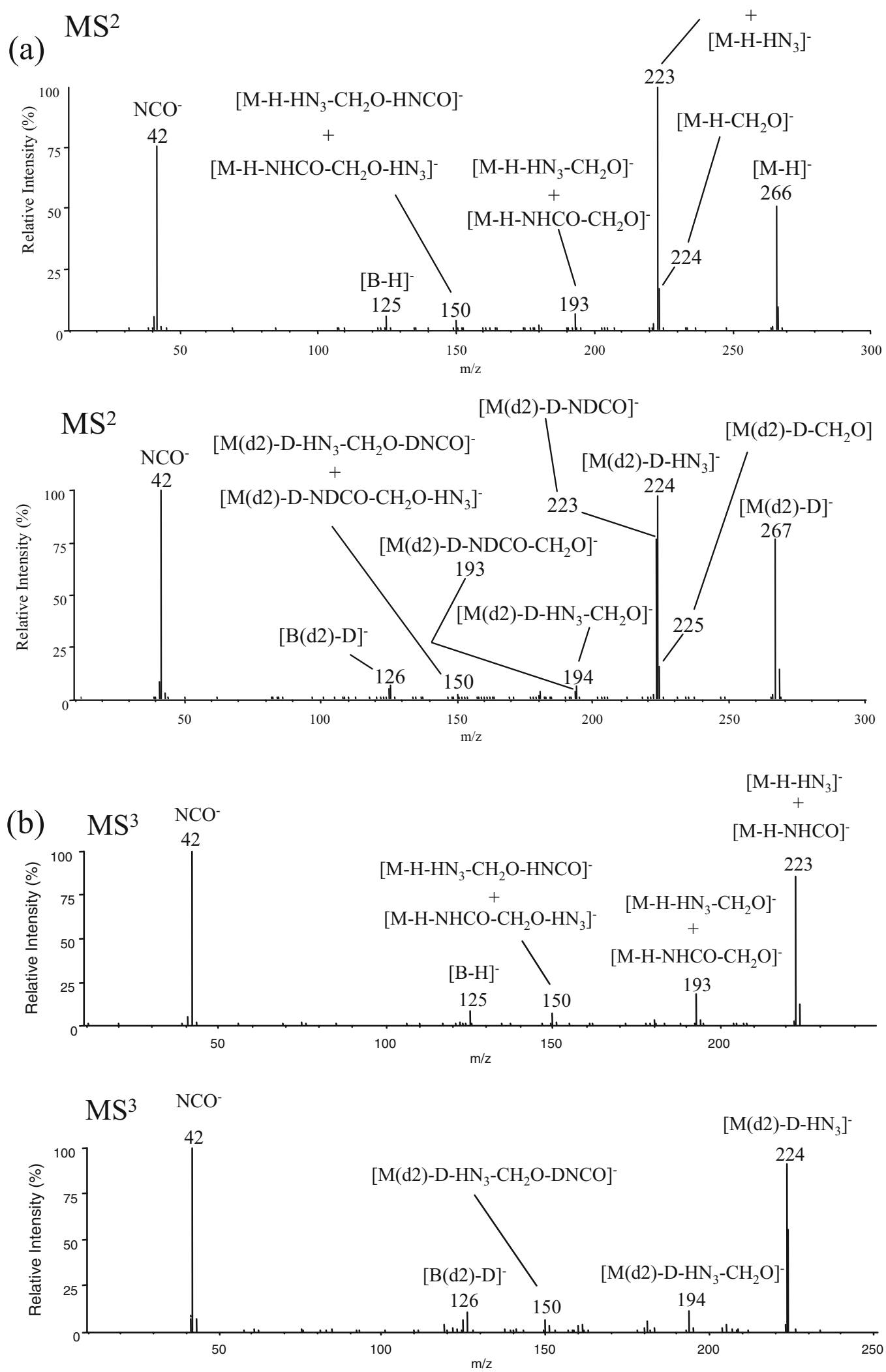

Figure 4. Negative ion ESI mass spectra of zidovudine (AZT, MW = 267): (a) CID product ion spectra $\left(\mathrm{MS}^{2}\right)$ of $[\mathrm{M}-\mathrm{H}]-$ at $m / z 266$ and the fully exchanged $[\mathrm{M}(\mathrm{d} 2)-\mathrm{D}]^{-}$at $\mathrm{m} / \mathrm{z} 267$ at a CE of 25 $\mathrm{eV}(\mathbf{b}) \mathrm{MS}^{3}$ generated by up-front CID of fragment ion at $\mathrm{m} / \mathrm{z} 223$ and its corresponding deuterated fragment ion at $m / z 224$. 

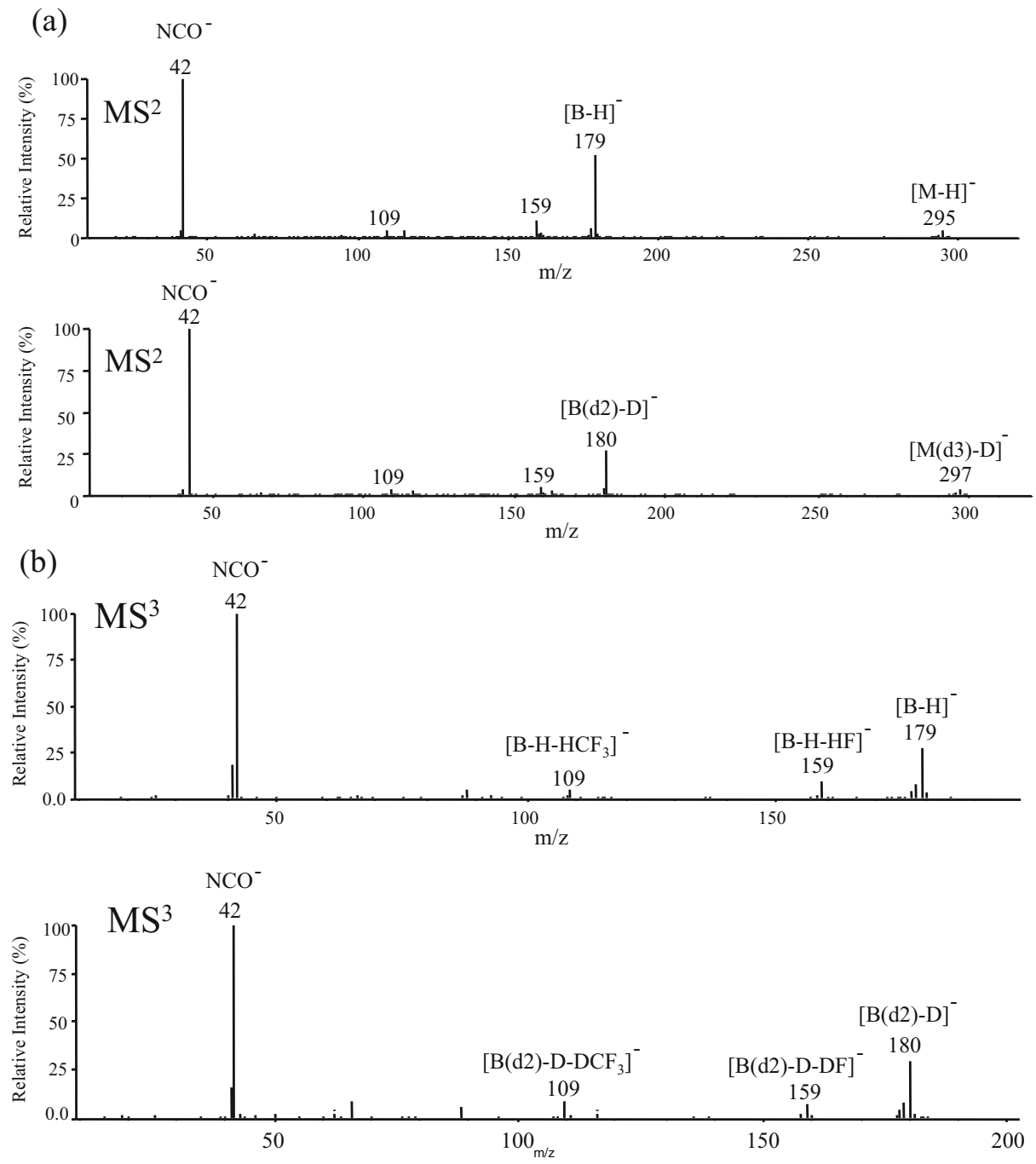

Figure 5. Negative ion ESI mass spectra of trifluridine (MW = 296): (a) CID product ion spectra $\left(\mathrm{MS}^{2}\right)$ of $[\mathrm{M}-\mathrm{H}]^{-}$at $m / z 295$ and the fully exchanged $[\mathrm{M}(\mathrm{d} 3)-\mathrm{D}]^{-}$at $m / z 297$ at a CE of $25 \mathrm{eV}$. (b) MS $^{3}$ generated by up-front CID of deprotonated base at $\mathrm{m} / \mathrm{z} 179$ and its corresponding deuterated fragment ion at $m / z 180$.

Small amounts of deprotonated/de-deuteronated thymine are observed at $\mathrm{m} / \mathrm{z} 125 / 126$. The major CID product of the negative ions at $223 / 224$ is the isocyanate ion at $m / z 42$.

\section{Collision-Induced Dissociation of Deprotonated Trifluridine}

Figure 5 shows the CID spectra of the $[\mathrm{M}-\mathrm{H}]^{-}$ions at $\mathrm{m} / \mathrm{z} 295$ from trifluridine and the $\left[\mathrm{M}\left(\mathrm{d}_{3}\right)-\mathrm{D}\right]^{-}$analog of the species at $\mathrm{m} / \mathrm{z} 297$. The almost exclusive fragment ions in the negative ion spectrum of trifluridine are the base ion, $[\mathrm{B}-\mathrm{H}]^{-}$, and $\mathrm{NCO}^{-}$.

The deprotonated trifluoromethyluracil ion at $\mathrm{m} / \mathrm{z}$ 179 in the CID spectrum from $\mathrm{m} / z 295$ (deprotonated trifluridine) is shifted to $\mathrm{m} / \mathrm{z} 180$ in the CID spectrum of the fully exchanged ion at $\mathrm{m} / \mathrm{z} 297$ - retaining one exchangeable $\mathrm{H} / \mathrm{D}$ in the deprotonated trifluoromethyluracil ion. Two minor competitive decomposi- tion pathways are observed for deprotonated trifluoromethyluracil at $\mathrm{m} / \mathrm{z} 179 / 180$ in Figure $5 \mathrm{~b}$. One decomposition pathway produces the fragment ion at $m / z 159$, by the loss of HF/DF. The second decomposition pathway includes expulsion of $\mathrm{HCF}_{3} / \mathrm{DCF}_{3}$ from $\mathrm{m} / \mathrm{z} 179 / 180$ to produce the fragment ion at $\mathrm{m} / \mathrm{z}$ 109. The prominent fragment ion at $m / z 42, \mathrm{NCO}^{-}$, in the CID spectra of $[\mathrm{M}-\mathrm{H}]^{-}$and $[\mathrm{B}-\mathrm{H}]^{-}$in Figure $5 b$ is also observed from decompositions of ions at $\mathrm{m} / \mathrm{z} 179 / 180$.

Scheme 3 shows a proposed mechanism for the loss of $\mathrm{HF}$ from $[\mathrm{B}-\mathrm{H}]^{-}$as well as the formation of $\mathrm{NCO}^{-}$. The prominent fragment ion $\mathrm{NCO}^{-}$could be derived directly from $[\mathrm{B}-\mathrm{H}]^{-}$or from $[\mathrm{B}-\mathrm{H}-$ $\mathrm{HF}]^{-}$in an analogy to RDA reaction.

The proton affinity of the anion, $\left(\mathrm{PA}\left(\mathrm{A}^{-}\right)\right.$, the enthalpy change associated with the gas-phase deprotonation reaction, $\mathrm{AH} \leftrightarrow \mathrm{A}^{-}+\mathrm{H}^{+}$, has been computed for different $\mathrm{NH}$ bonds of uracil and 
(a)

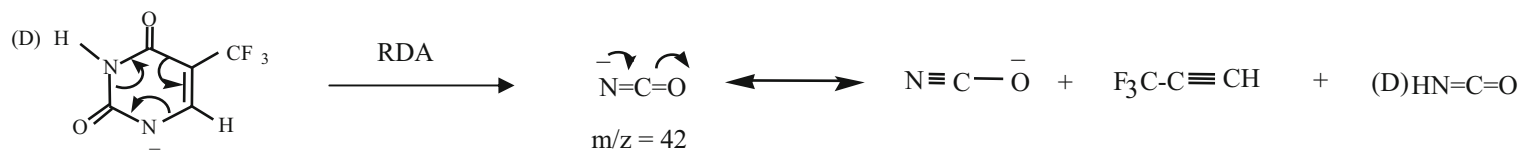

$\mathrm{m} / \mathrm{z}=179$

(b)

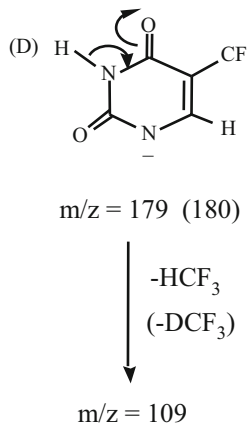

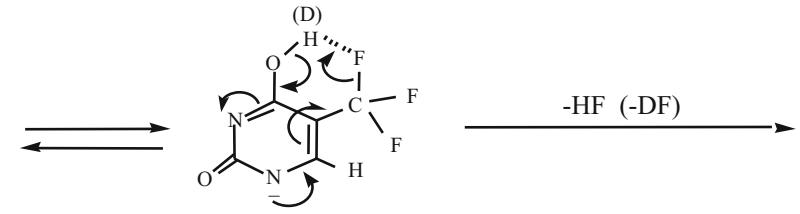
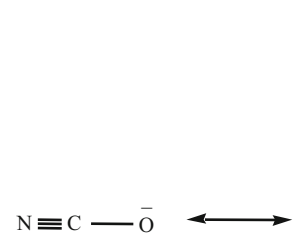

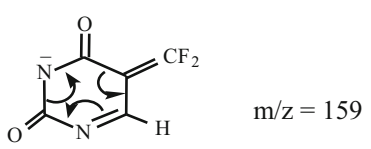

RDA

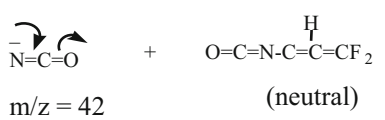

Scheme 3. Proposed CID fragmentation mechanisms of deprotonated base $[\mathrm{B}-\mathrm{H}]^{-}$of trifluridine at $\mathrm{m} / \mathrm{z} 179$ determined from both $\mathrm{H} / \mathrm{D}$ exchange patterns and $\mathrm{MS}^{3}$ experiments. The formation of fragment ion at $m / z 42$ could be derived directly from (a) $[\mathrm{B}-\mathrm{H}]^{-}$at $\mathrm{m} / \mathrm{z} 179$ and from (b) decomposition of [B $\mathrm{H}-\mathrm{HF}^{-}$at $m / z 159$. Numbers in parentheses refer to deuterated fragment ions.

thymine [57]. For uracil, the $\mathrm{PA}\left(\mathrm{A}^{-}\right)$values for $\mathrm{N} 1 \mathrm{H}$ and $\mathrm{N} 3 \mathrm{H}$ were reported to be $1391 \mathrm{~kJ} / \mathrm{mol}$ and 1447 $\mathrm{kJ} / \mathrm{mol}$, respectively. For thymine, the $\mathrm{PA}\left(\mathrm{A}^{-}\right)$values for $\mathrm{N} 1 \mathrm{H}$ and $\mathrm{N} 3 \mathrm{H}$ were computed slightly higher at $1398 \mathrm{~kJ} / \mathrm{mol}$ and $1450 \mathrm{~kJ} / \mathrm{mol}$, respectively. These values indicate that the proton at N1 is more acidic and hence more easily removed than that at N3 and that uracil is more acidic than thymine. These values are consistent with the $\mathrm{pK}_{\mathrm{a} 2}$ values reported for $\mathrm{N} 3 \mathrm{H}$ of thymidine and uridine (Table 1): uridine is more acidic than thymidine. Solution data for nucleosides (Table 1) are interpreted that the $\mathrm{N} 3 \mathrm{H}$ proton is removed first and then the ribose $\mathrm{OH}$.

The major collisionally induced dissociation of deprotonated trifluoromethyluracil is the formation of $\mathrm{NCO}^{-}$ion by RDA mechanism. Eliminations of HF and $\mathrm{HCF}_{3}$ are minor decomposition pathways. The dissociation reactions are interpreted in terms of decomposition of ions deprotonated on the trifluoromethyluracil ring.

\section{Collision-Induced Dissociation of Deprotonated 5-Iodo-2', 3'-Dideoxyuridine}

The CID spectra (not shown) of $[\mathrm{M}-\mathrm{H}]^{-}$and $\left[\mathrm{M}\left(\mathrm{d}_{2}\right)-\right.$ $\mathrm{D}]^{-}$ions of 5-iodo-2', $3^{\prime}$-dideoxyuridine at $\mathrm{m} / \mathrm{z} 337$ and 338 at collision energy of $25 \mathrm{eV}$ contain ions from the expulsion of $\mathrm{HNCO} / \mathrm{DNCO}$ by RDA to produce the fragment ion at $\mathrm{m} / \mathrm{z} 294$ which contains no exchangeable hydrogen. The deprotonated 5-iodouracil at $\mathrm{m} / \mathrm{z} 237$ is shifted almost exclusively to $m / z 238$.

The fragment ion at $\mathrm{m} / \mathrm{z} 127$ in the CID spectrum from $[\mathrm{M}-\mathrm{H}]^{-}$at $\mathrm{m} / \mathrm{z} 337$ contains no exchangeable $\mathrm{H}$ because there is no ion at $\mathrm{m} / \mathrm{z} 128$ in the CID spectrum of the fully exchanged species at $m / z 338$ and is assigned to the iodide ion. This ion could be derived directly from $[\mathrm{M}-\mathrm{H}]^{-}$and from decomposition of $[\mathrm{B}-\mathrm{H}]^{-}$ions. The major fragment ion at $\mathrm{m} / \mathrm{z} 42$ also contains no exchangeable $\mathrm{H}$ and is assigned to $\mathrm{NCO}^{-}$. This prominent fragment ion could be derived directly from $[\mathrm{M}-\mathrm{H}]^{-}$or from $[\mathrm{B}-\mathrm{H}]^{-}$as discussed earlier in this paper.

The principal pathway for CID of deprotonated base (5-iodouracil) at $\mathrm{m} / \mathrm{z} 237 / 238$ produces the fragment ion at $\mathrm{m} / \mathrm{z} 42, \mathrm{NCO}^{-}$. One minor decomposition pathway produces the fragment ion at $\mathrm{m} / \mathrm{z} 194$, which is generated by the loss of $\mathrm{HNCO} / \mathrm{DNCO}$ from $\mathrm{m} / \mathrm{z} 237 / 238$. The second minor decomposition pathway produces the iodide ion at $\mathrm{m} / \mathrm{z}$ 127. A third minor decomposition pathway involves the loss of an iodine atom to produce the fragment ions at $\mathrm{m} / \mathrm{z} 110 / 111$ followed by decarbonylation to give ions at $\mathrm{m} / \mathrm{z} 82 / 83$.

\section{Collision-Induced Dissociation of Deprotonated 5-Iodo-2'-Deoxyuridine}

The CID spectra (not shown) of $\mathrm{m} / \mathrm{z} 353$ for $[\mathrm{M}-\mathrm{H}]^{-}$of 5-iodo-2'-deoxyuridine and of $\mathrm{m} / \mathrm{z} 355$ for the fully exchanged species at collision energy of $25 \mathrm{eV}$ show expulsion of $\mathrm{HNCO} / \mathrm{DNCO}$ by RDA to produce the fragment ion at $\mathrm{m} / \mathrm{z} 310 / 311$ which contains one exchangeable hydrogen. Similar to the observations above for 5-iodo$2^{\prime}, 3^{\prime}$-dideoxyuridine the deprotonated 5-iodouracil at $\mathrm{m} / \mathrm{z}$ 237 is shifted almost exclusively to $\mathrm{m} / \mathrm{z} 238$.

As noted above, the fragment ions at $m / z 127$ and 42 contain no exchangeable $\mathrm{H}$ and are assigned to the iodide ion and $\mathrm{NCO}^{-}$, respectively.

The CID spectra of deprotonated 5-iodouracil at $\mathrm{m} / \mathrm{z}$ 237 and the fully exchanged species at $\mathrm{m} / \mathrm{z} 238$ are the 
Table 3. Principal dissociation products of deprotonated antivirals

\begin{tabular}{|c|c|c|c|}
\hline Product ion & Mass-to-charge ratio & Deuterated product ion & Deuterated mass-to-charge ratio \\
\hline \multicolumn{4}{|c|}{ zidovudine AZT $\left(\mathrm{MW}=267,[\mathrm{M}-\mathrm{H}]^{-}=266,[\mathrm{M}(\mathrm{d} 2)-\mathrm{D}]^{-}=267\right)$} \\
\hline $266-\mathrm{CH}_{2} \mathrm{O}$ & 224 & $267-\mathrm{CH}_{2} \mathrm{O}$ & 225 \\
\hline $266-\mathrm{NHCO}$ & 223 & $267-\mathrm{NDCO}$ & 223 \\
\hline $266-\mathrm{HN}_{3}$ & 223 & $267-\mathrm{HN}_{3}$ & 224 \\
\hline $223-\mathrm{CH}_{2} \mathrm{O}$ & 193 & $223-\mathrm{CH}_{2} \mathrm{O} / 224-\mathrm{CH}_{2} \mathrm{O}$ & $193 / 194$ \\
\hline $193-\mathrm{HNCO}$ & 150 & $193-\mathrm{HN}_{3} / 194-\mathrm{DNCO}$ & 150 \\
\hline $266-141$ & 125 & $267-141$ & 126 \\
\hline $\mathrm{NCO}^{-}$ & 42 & $\mathrm{NCO}^{-}$ & 42 \\
\hline \multicolumn{4}{|c|}{ trifluridine $\left(\mathrm{MW}=296,[\mathrm{M}-\mathrm{H}]^{-}=295,[\mathrm{M}(\mathrm{d} 3)-\mathrm{D}]^{-}=297\right)$} \\
\hline $295-116$ & 179 & $297-117$ & 180 \\
\hline $179-\mathrm{HF}$ & 159 & $180-\mathrm{DF}$ & 159 \\
\hline $179-\mathrm{HCF}_{3}$ & 109 & $179-\mathrm{DCF}_{3}$ & 109 \\
\hline $\mathrm{NCO}^{-}$ & 42 & $\mathrm{NCO}^{-}$ & 42 \\
\hline \multicolumn{4}{|c|}{ 5-iodo-2'-deoxyuridine $\left(\mathrm{MW}=354,[\mathrm{M}-\mathrm{H}]^{-}=353,[\mathrm{M}(\mathrm{d} 3)-\mathrm{D}]^{-}=355\right)$} \\
\hline $353-\mathrm{HNCO}$ & 310 & $355-$ DNCO & 311 \\
\hline $353-116$ & 237 & $355-117$ & 238 \\
\hline $237-\mathrm{HNCO}$ & 194 & $238-$ DNCO & 194 \\
\hline $\mathrm{I}^{-}+\mathrm{Cl}^{-}$ & 127 & $\mathrm{I}^{-}$ & 127 \\
\hline $237-1$ & 110 & $238-1$ & 111 \\
\hline $110-\mathrm{CO}$ & 82 & $111-\mathrm{CO}$ & 83 \\
\hline $\mathrm{NCO}^{-}$ & 42 & $\mathrm{NCO}^{-}$ & 42 \\
\hline \multicolumn{4}{|c|}{ 5-iodo-2 ${ }^{\prime}, 3^{\prime}$-dideoxyuridine $\left(\mathrm{MW}=338,[\mathrm{M}-\mathrm{H}]^{-}=337,[\mathrm{M}(\mathrm{d} 2)-\mathrm{D}]^{-}=338\right)$} \\
\hline $337-\mathrm{HNCO}$ & 294 & 338 - DNCO & 294 \\
\hline $337-100$ & 237 & $338-100$ & 238 \\
\hline 237 - HNCO & 194 & 238 - DNCO & 194 \\
\hline $\mathrm{I}^{-}$ & 127 & $\mathrm{I}^{-}$ & 127 \\
\hline $237-1$ & 110 & $238-1$ & 111 \\
\hline $110-\mathrm{CO}$ & 82 & $111-\mathrm{CO}$ & 83 \\
\hline $\mathrm{NCO}^{-}$ & 42 & $\mathrm{NCO}^{-}$ & 42 \\
\hline
\end{tabular}

same as the CID spectra of these ions from 5-iodo- $2^{\prime}, 3^{\prime}-$ dideoxyuridine, discussed previously.

Table 3 shows the principal dissociation products of four deprotonated pyrimidine derivatives. The decomposition processes discussed above have some similarities and differences. All of the pyrimidine derivatives gave ions corresponding to $[\mathrm{B}-\mathrm{H}]^{-}$and $\mathrm{NCO}^{-}$. Elimination of $\mathrm{CH}_{2} \mathrm{O}, \mathrm{HNCO}$ (DNCO) and $\mathrm{HN}_{3}$ were observed for deprotonated AZT. Deprotonated trifluridine, however, showed the expulsion of HF (DF). Loss of HNCO (DNCO), CO and formation of iodide ion were observed for the deprotonated 5-iodo-uracil derivatives.

\section{Conclusions}

Gas-phase H/D exchange in the nebulizer region allowed easy determination of the number of replaceable hydrogens in AZT (zidovudine), trifluridine, 5-iodo-2'-deoxyuridine, and 5-iodo-2' $3^{\prime}$ ' dideoxyuridine, and aided in the interpretation of the collisionally induced decomposition reactions of the protonated species-clearly differentiating between fragment ions derived from the base and those derived from the sugar moiety of these pyrimidine antiviral agents. The CID spectra of $[\mathrm{M}-\mathrm{H}]^{-}$ions from antiviral agents contained predominantly $\mathrm{NCO}^{-}$ions and virtually no sugar ions.
Protonated AZT, with a basic thymine residue, is collisionally decomposed primarily to protonated thymine and only small amounts of sugar ions. The other antiviral agents, with $\mathrm{I}$ or $\mathrm{CF}_{3}$ instead of $\mathrm{CH}_{3}$ on the pyrimidine ring, show significantly higher abundances of sugar ions than protonated base as CID products. Protonated pyrimidine bases dissociate through three principal pathways: (1) elimination of $\mathrm{NH}_{3}$, (2) loss of $\mathrm{H}_{2} \mathrm{O}$, and (3) elimination of NHCO. Protonated trifluoromethyluracil, however, dissociates primarily through elimination of HF followed by loss of NHCO.

CID spectra of $[\mathrm{M}-\mathrm{H}]^{-}$ions of all four antiviral agents show $\mathrm{NCO}^{-}$as the principal decomposition product. A lesser amount of deprotonated base is formed from cleavage of the glycosidic bond with charge delocalization on the base. Elimination of $\mathrm{HNCO}, \mathrm{HF}, \mathrm{HN}_{3}, \mathrm{CO}$, and formation of iodide ion are minor dissociation pathways from $[\mathrm{M}-\mathrm{H}]^{-}$ions.

The mass spectra of the antiviral agents under investigation can serve as useful models for determination of the structures of chemically or biologically modified antiviral agents that often contribute to biological activities, both desirable and harmful. Knowledge of the fragmentation pathways could also help in selective quantitative determination of these compounds in complex matrices. 


\section{References}

1. Lefebvre, I.; Pompon, A.; Valette, G.; Perigaud, C.; Gosselin, G.; Imbach, J.-L. Online cleaning HPLC-UV-MS: A Tool for Analyzing New AntiHIV Drugs in Biological Media. L. Chromatogr. Gas Chromatogr. 1997, 15 , $868-876$.

2. McGuigan, C.; Tsang, H.-W.; Cahard, D.; Turner, K.; Velazquez, S.; Salgado, A.; Bidois, L.; Naesens, L.; De Clercq, E.; Balzarini, J. Phosphoramidate Derivatives of d4T as Inhibitors of HIV: The Effect of Amino Acid Variation. Antiviral. Res. 1997, 35, 195-204.

3. Roberts, W. L.; Buckley, T. J.; Rainey, P. M.; Jatlow, P. I. Solid-Phase Extraction Combined with Radioimmunoassay for Measurement of Zalcitabine $\left(2^{\prime}, 3^{\prime}\right.$-Dideoxycytidine) in Plasma and Serum. Clin. Chem. 1994, 40, 211-215.

4. Szinai, I.; Veres, Z.; Ganzler, K.; Hegedus-Vajda, J.; De Clercq, E. Metabolism of Anti-Herpes Agent 5-(2-Chloroethyl)-2'-Deoxyuridine in Mice and Rats. Eur. J. Met. Pharmacok. 1991, 16, 129-136.

5. Kreutzberger, A; Sellheim, M. Antiviral Agents, XXVI. Synthesis of 4,6-Disubstituted 2-(Cyanoamino)Pyrimidines and Studies of Their Structure by Mass Spectroscopy. Chemiker. Zeitung. 1984, 108, 253-255.

6. Kreutzberger, A.; Richter, B. Tumor-Inhibiting Substances. XIII. 2-Perfluoroalkylpyrimido[1,2-a]Benzimidazoles with Aromatic Carbocyclic and Heterocyclic Substituents. J. Fluorine Chem. 1982, 20, 227-240.

7. Biemann, K.; McCloskey, J. Application of Mass Spectrometry to Structure Problems. VI. Nucleosides. J. Am. Chem. Soc. 1962, 84, 20052007.

8. Crain, P. F. Mass Spectrometric Techniques in Nucleic Acid Research. Mass Spectrom. Rev. 1990, 9, 505-554.

9. Sakurai, T.; Matsuo, T.; Kusai, A.; Nojima, K. Collisionally Activated Decomposition Spectra of Normal Nucleosides and Nucleotides Using a Four-Sector Tandem Mass Spectrometer. Rapid Commun. Mass Spectrom. 1989, 3, 212-216.

10. Wilson, M. S.; McCloskey, J. A. Chemical Ionization Mass Spectrometry of Nucleosides. Mechanisms of Ion Formation and Estimations of Proton Affinity. J. Am. Soc. Mass Spectrom. 1975, 97, 3436-3444.

11. Crow, F. W.; Tomer, K. B.; Gross, M. L.; McCloskey, J. A.; Bergstrom, D. E. Fast Atom Bombardment Combined with Tandem Mass Spectrometry for the Determination of Nucleosides. Anal. Biochem. 1984, 139, 243-262.

12. Reddy, D.; Iden, C. R. Analysis of Modified Deoxynucleosides by Electrospray Ionization Mass Spectrometry. Nucleosides Nucleotides. 1993, 12, 815-826.

13. Frelon, S.; Douki, T.; Ravanat, J.-L.; Pouget, J.-P.; Tornabene, C.; Cadet, J. High-Performance Liquid Chromatography-Tandem Mass Spectrometry Measurement of Radiation-Induced Base Damage to Isolated and Cellular DNA. Chem. Res. Toxicol. 2000, 13, 1002-1010.

14. Hua, Y.; Wainhaus, S. B.; Yang, Y.; Shen, L.; Xiong, Y.; Xu, X.; Zhang, F.; Bolton, J. L.; van Breemen, R. B. Comparison of Negative and Positive Ion Electrospray Tandem Mass Spectrometry for the Liquid Chromatography Tandem Mass Spectrometry Analysis of Oxidized Deoxynucleosides. J. Am. Soc. Mass Spectrom. 2001, 12, 80-87.

15. Wang, Y.; Vivekananda, S.; Zhang, K. ESI-MS/MS for the Differentiation of Diastereomeric Pyrimidine Glycols in Mononucleosides. Anal. Chem. 2002, 74, 4505-4512.

16. Zhang, Q.; Wang, Y. Differentiation of 2'-O- and 3'-O-Methylated Ribonucleosides by Tandem Mass Spectrometry. J. Am. Soc. Mass Spectrom. 2006, 17, 1096-1099.

17. Ovcharenko, V.; Szacon, E.; Tkaczynski, T.; Matosiuk, D.; Pihlajal, K. Electron Impact Mass Spectra of Substituted 1-Aryl-2-Arylsulfonylamino-1,4,5,6-Tetrahydropyrimidines. Rapid Commun. Mass Spectrom. 1997, 11, 1407-1410.

18. Nelson, C. C.; McCloskey, J. A. Collision-Induced Dissociation of Uracil and Its Derivatives. J. Am. Soc. Mass Spectrom. 1994, 5, 339-349.

19. Ramsey, R. S.; Van Berkel, G. J.; McLuckey, S. A.; Glish, G. L. Determination of Pyrimidine Cyclobutane Dimers by Electrospray Ionization/Ion Trap Mass Spectrometry. Biol. Mass Spectrom. 1992, 21, 347-352.

20. Rice, J. M.; Dudek, G. O.; Barber, M. Mass Spectra of Nucleic Acid Derivatives. Pyrimidines. J. Am. Chem. Soc. 1965, 87, 4569-4576.

21. Bruins, A.P.; Covey, T. R.; Henion, J. D. Ion Spray Interface for Combined Liquid Chromatography/Atmospheric Pressure Ionization Mass Spectrometry. Anal. Chem. 1987, 59, 2642-2646.

22. Loo, J. A.; Udseth, H. R.; Smith, R. D. Collisional Effects on the Charge Distribution of Ions from Large Molecules, Formed by ElectrosprayIonization Mass Spectrometry. Rapid Commun. Mass Spectrom. 1988, 2, 207-210.

23. Edlund, P. O.; Lee, E. D.; Henion, J. D.; Budde, W. L. The Determination of Sulfonated Azo Dyes in Municipal Waste Water by Ion Spray Liquid Chromatography Tandem Mass Spectrometry. Biomed. Env. Mass Spectrom. 1989, 18, 233-240.

24. Wang, Y. Y.; Lyttle, M. H.; Borer, P. N. Enzymic and NMR Analysis of Oligoribonucleotides Synthesized with 2'-Tert-Butyldimethylsilyl Protected Cyanoethylphosphoramidite Monomers. Nucleic Acids Res. 1990, $18,3347-3352$.

25. Straub, R.; Voyksner, R. D.; Keever, J. T. Thermospray, Particle Beam and Electrospray Liquid Chromatography-Mass Spectrometry of Azo Dyes. J. Chromatogr. 1992, 627, 173-186.

26. Crow, F. W.; Tomer, K. B.; Gross, M. L.; McCloskey, J. A.; Bergstrom, D. E. Fast Atom Bombardment Combined with Tandem Mass Spec- trometry for the Determination of Nucleosides. Anal. Biochem. 1984, 139, 243-262.

27. Smith, D. L.; Schram, K. H.; McCloskey, J. A. The Negative Ion Mass Spectra of Selected Nucleosides. Biomed. Mass Spectrom. 1983, 10, 269-275.

28. Claereboudt, J.; Esmans, E. L.; Claeys, M. Mass Spectral Behavior of (M $-\mathrm{H})^{-}$Ions of Some Pyrimidine Nucleosides. Biol. Mass Spectrom. 1993, $22,419-421$.

29. Mahrwald, R.; Schwarz, W. Mass Spectroscopic Studies of 5-Halogenated Pyrimidine Glucuronides. J. Prak. Chem. 1982, 324, 177-186.

30. Rozenski, J.; Meier, C.; Aubagnac, J.-L.; Astier, R.; Herdewijn, P.; Imbach, J.-L.; Gosselin, G. Fast-Atom Bombardment Mass Spectrometric Study of SATE Foscarnet Pro-Drugs and of a Series of Foscarnet-AZT Conjugates. Rapid Commun. Mass Spectrom. 1997, 11, 1212-1218.

31. McCloskey, J. A. Introduction of Deuterium by Exchange for Measurement by Mass Spectrometry. Methods Enzymol. 1990, 193, 329-338.

32. Hass, G. W.; Giblin, D. E.; Gross, M. L. The Mechanism and Thermodynamics of Transesterification of Acetate-Ester Enolates in the Gas Phase. Int. J. Mass Spectrom. Ion Processes 1998, 172, 25-46.

33. Adejare, A.; Brown, P. W. Hydrogen/Deuterium Exchange to Differentiate Fragment Ions from Pseudomolecular Ions by Electrospray Tandem Mass Spectrometry. Anal. Chem. 1997, 69, 1525-1529.

34. Ni, J.; Harrison, A. G. Reactive Collisions in Quadrupole Cells. VI. H/D Exchange Reactions of Protonated Alkylbenzenes with D2O, CH3OD, and C2H5OD. Can. J. Chem. 1995, 73, 1779-1184.

35. Feistner, G. J.; Hsieh, L. L. Metabolites of Erwinia. Part II. On the Collision-Activated Fragmentation of Proferrioxamines: Evidence for a Succinimide-Mediated Mechanism. J. Am. Soc. Mass Spectrom. 1995, 6, $836-846$.

36. Dookeran, N. N.; Harrison, A. G. Reactive Collisions in Quadrupole Cells. III. H/D Exchange Reactions of Protonated Aromatic Amines with $\mathrm{ND}_{3}$. I. Am. Soc. Mass Spectrom. 1995, 6, 19-26.

37. Cushnir, J. R.; Naylor, S.; Lamb, J. H.; Farmer, P. B. Deuterium Exchange Studies in the Identification of Alkylated DNA Bases Found in Urine, by Tandem Mass Spectrometry. Rapid Commun. Mass Spectrom. 1990, 4, $426-431$.

38. Kamel, A. M.; Fouda, H. G.; Brown, P. R.; Munson, B. Mass Spectral Characterization of Tetracyclines by Electrospray Ionization, H/D Exchange, and Multiple Stage Mass Spectrometry. J. Am. Soc. Mass Spectrom. 2002, 13, 543-557.

39. Kamel, A. K.; Munson, B. Collision-Induced Dissociation of Purine Antiviral Agents: Mechanisms of Ion Formation Using Gas-Phase Hydrogen/Deuterium Exchange and Electrospray Ionization Tandem Mass Spectrometry. Eur. J. Mass Spectrom. 2004, 10, 239-257.

40. Hemling, M. E.; Conboy, J. J.; Bean, M. F.; Mentzer, M.; Carr, S. A Gas-Phase Hydrogen/Deuterium Exchange in Electrospray Ionization Mass Spectrometry as a Practical Tool for Structure Elucidation. J. Am. Soc. Mass Spectrom. 1994, 5, 434-442.

41. Kamel, A. M.; Brown, P. R.; Munson, B. Effects of Mobile-Phase Additives, Solution $\mathrm{pH}$, Ionization Constant, and Analyte Concentration on the Sensitivities and Electrospray Ionization Mass Spectra of Nucleoside Antiviral Agents. Anal. Chem. 1999, 71, 5481-5492.

42. Izatt, R. M.; Christensen, J. J.; Rytting, J. H. Sites and Thermodynamic Quantities Associated with Proton and Metal Ion Interaction with Ribonucleic Acid, Deoxyribonucleic Acid, and Their Constituent Bases, Nucleosides, and Nucleotides. Chem. Rev. 1971, 71, 439-482.

43. Lonnberg, H. Proton and metal ion interaction with nucleic acid bases, nucleosides, and nucleoside monophosphates. In: Biocoordination Chemistry; Kalman, B., Ed.; Ellis Horwood: London, 1990; pp 284-346.

44. Shionoya, M.; Kimura, E.; Shiro, M. A New Ternary Zinc(II) Complex with [12] aneN4 (=1,4,7,10-Tetraazacyclododecane) and AZT $\left(=3^{\prime}\right.$ Azido-3'-Deoxythymidine). Highly Selective Recognition of Thymidine and Its Related Nucleosides by a Zinc(II) Macrocyclic Tetra-Amine Complex with Novel Complementary Associations. J. Am. Chem. Soc. 1993, 115, 6730-6737.

45. Christensen, J. J.; Rytting, J. H.; Izatt, R. M. Thermodynamics of Proton Dissociation in Dilute Aqueous Solution. VIII. pK Change in Heat Content and Change in Entropy Values for Proton Ionization from Several Pyrimidines and Their Nucleosides at 25 Degrees. J. Phys. Chem. $1967,71,2700-2705$.

46. Wataya, Y.; Sonobe, Y.; Maeda, M.; Yamaizumi, Z.; Aida, M.; Santi, D. V. Reaction of 5-Trifluoromethyl-2'-Deoxyuridine and 1-Methyl-5Trifluoromethyluracil with Methoxyamine: Model Studies for the Interaction Between Thymidylate Synthetase and 5-Trifluoromethyl-2'-Deoxyuridine 5'-Phosphate. J. Chem. Soc. Perkin Trans. 1987, 1, 2141-2147.

47. Shionoya, M.; Ikeda, T.; Kimura, E.; Shiro, M. Novel "Multipoint" Molecular Recognition of Nucleobases by a New Zinc(II) Complex of Acridine-Pendant Cyclen (Cyclen = 1,4,7,10-Tetraazacyclododecane) J. Am. Chem. Soc. 1994, 116, 3848-3859.

48. Molecular Modeling and Computational Chemistry Department, Pfizer Inc. ZPARC (Performs Automatic Reasoning in Chemistry) Version 1.1, ChemLogic Inc.

49. Liguori, A.; Napoli, A.; Sindona, G.; Survey of the Proton Affinities of Adenine, Cytosine, Thymine, and Uracil Dideoxyribonucleosides, Deoxyribonucleosides, and Ribonucleosides. J. Mass Spectrom. 2000, 35, $139-144$.

50. Mezzache, S.; Alves, S.; Pepe, C.; Quelquejeu, M.; Fournier, F.; Valery, J.-M.; Tabet, J.-C. Proton Affinity Ladder for Uridine and Analogs Influence of the Hydroxyl Group on the Sugar Ring Conformation. J. Mass Spectrom. 2005, 40, 722-730. 
51. Rodgers, M. T.; Armentrout, P. B. Noncovalent Interactions of Nucleic Acid Bases (Uracil, Thymine, and Adenine) with Alkali Metal Ions. Threshold Collision-Induced Dissociation and Theoretical Studies. J. Am. Chem. Soc. 2000, 122, 8548-8558.

52. DiDonna, L.; Napoli, A.; Sindona, G.; Athanassopoulos, C. A Comprehensive Evaluation of the Kinetic Method Applied in the Determination of the Proton Affinity of the Nucleic Acid Molecules. J. Am. Soc. Mass Spectrom. 2004, 15, 1080-1086.

53. Podolyan, Y.; Gorb, L.; Leszczynski, J. Protonation of Nucleic Acid Bases. A Comprehensive Post-Hartree-Fock Study of the Energetics and Proton Affinities. J. Phys. Chem. A 2000, 104, 7346-7352.

54. Russo, N.; Toscano, M.; Grand, A.; Jalibois, F. Protonation of Thymine, Cytosine, Adenine, and Guanine DNA Nucleic Acid Bases: Theoretical
Investigation into the Framework of Density Functional Theory. J. Comput. Chem. 1998, 19, 989-1000.

55. Zeegers-Huyskens, T. The Basicity of the Two Carbonyl Bonds in Uracil Derivatives. J. Mol. Struct. 1989, 198, 135-142.

56. Cao, H.; Wang, Y. Collisionally Activated Dissociation of Protonated 2'-Deoxycytidine, 2'-Deoxyuridine, and their Oxidatively Damaged Derivatives. J. Am. Soc. Mass Spectrom. 2006, 17, 1335-1341.

57. Chandra, A. K.; Nguyen, M. T.; Uchimaru, T.; Zeegers-Huyskens, T. Protonation and Deprotonation Enthalpies of Guanine and Adenine and Implications for the Structure and Energy of Their Complexes with Water: Comparison with Uracil, Thymine, and Cytosine. J. Phys. Chem. A 1999, 103, 8853-8860. 